\title{
17 MASTER
}

g/ $31 / 5$
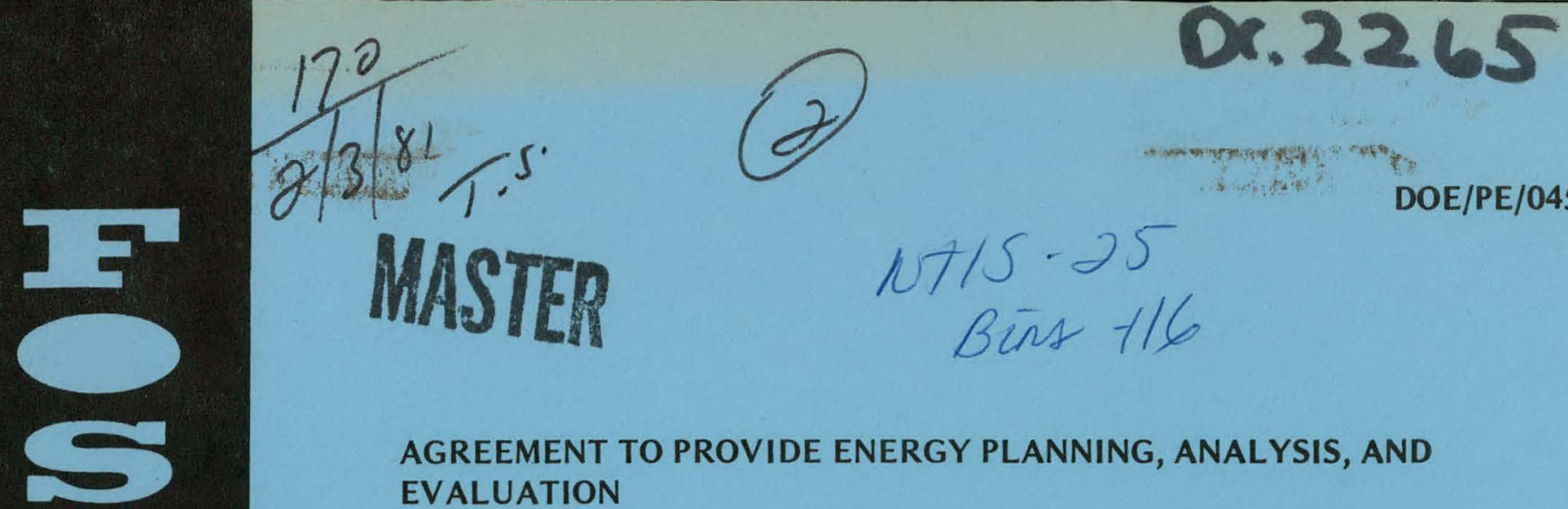

AGREEMENT TO PROVIDE ENERGY PLANNING, ANALYSIS, AND EVALUATION

Final Report

March 1980

Work Performed Under Contract No. AC02-77PE04505

Institute of Gas Technology

IIT Center

Chicago, Illinois

\section{U. S. DEPARTMENT OF ENERGY}




\section{DISCLAIMER}

This report was prepared as an account of work sponsored by an agency of the United States Government. Neither the United States Government nor any agency Thereof, nor any of their employees, makes any warranty, express or implied, or assumes any legal liability or responsibility for the accuracy, completeness, or usefulness of any information, apparatus, product, or process disclosed, or represents that its use would not infringe privately owned rights. Reference herein to any specific commercial product, process, or service by trade name, trademark, manufacturer, or otherwise does not necessarily constitute or imply its endorsement, recommendation, or favoring by the United States Government or any agency thereof. The views and opinions of authors expressed herein do not necessarily state or reflect those of the United States Government or any agency thereof. 


\section{DISCLAIMER}

Portions of this document may be illegible in electronic image products. Images are produced from the best available original document. 


\section{DISCLAIMER}

"This book was prepared as an account of work sponsored by an agency of the United States Government. Neither the United States Government nor any agency thereof, nor any of their employees, makes any warranty, express or implied, or assumes any legal liability or responsibility for the accuracy, completeness, or usefulness of any information, apparatus, product, or process disclosed, or represents that its use would not infringe privately owned rights. Reference herein to any specific commercial product, process, or service by trade name, trademark, manufacturer, or otherwise, does not necessarily constitute or imply its endorsement, recommendation, or favoring by the United States Government or any agency thereof. The views and opinions of authors expressed herein do not necessarily state or reflect those of the United States Government or any agency thereof."

This report has been reproduced directly from the best available copy.

Available from the National Technical Information Service, U. S. Department of Commerce, Springfield, Virginia 22161.

Price: Printed Copy A05

Microfiche A01 


\title{
AGREEMENT TO PROVIDE ENERGY PLANNING, ANALYSIS, AND EVALUATION
}

Final Report

IGT Project No. 61020

\author{
Frepared for \\ Department of Energy \\ (Contract No. DE-AC02-77PE04505)
}

March 1980

Institute of Gas Technology

IIT Center

Chicago, Illinois 
This is a final report concluding work performed under DOE Contract No. EX-77-C-02-4505, IGT Project No. 61020, "Agreement to Provide Energy Planning, Analysis, and Evaluation." Under this program, IGT conducted and prepared three separate analyses as requested by DOE. These analyses are - Incremental Pricing and LNG Projects

- Cooperative Arab/Israeli Energy Programs Based on Natural Gas

- An Examination of FEA Region 5 with Regard to the Natural Gas Policy Act of 1978.

The task reports for each of these analyses are included in this final report. 
INCREMENTAI PRICING AND LNG PROJECTS

$\$$ 
INTRODUCTION

As part of our efforts under Contract EX-77-C-02-4505, Mr. Henry Santiago, then Acting Director of the Office of Oil and Gas Policy, asked IGT for a quick response appraisal of the potential effects resulting from a possible requirement that gas from all future LNG projects be priced incremental1y. The results of this appraisal are contained in the following text and the three attached appendices.

\section{ASSUMPTIONS}

The key assumptions that we have made are the following:

- The projects are those which have not yet filed applications with FERC - The projects do not include gas originating in Mexico, Canada, or Alaska

- The incremental pricing extends through the end-user, i.e., the burner tip

- A significant shortage of non-coal fossil fuel will occur worldwide by the end of this century

- Prices for LNG will increase during the course of a given contract according to escalation rates tied to oil and oil product prices

- Over the long run, incrementally priced LNG will be more expensive than most available alternatives on a cost per Btu basis.

Of these assumptions, the most controversial deals with the relative cost of LNG versus alternatives. This assumption is based on a number of factors. First, the escalation rates in the purchase contracts with exporting countries will hold LNG prices above those for distillate and residual fuel oil. Second, the transportation costs for LNG are high. Exporters from Africa, Indonesia, and the Middle East will be able to charge higher wellhead prices to Europe, India, and Japan than to the U.S. because less of the delivered costs are taken up by transportation charges. Third, projected prices for synthetic fuels are lower than the projected prices for LNG after 1990. Fourth, the projected costs for imported LPG's and naphtha are lower than those for LNG because of the lower transportation costs. Fifth, the countries exporting gas are not noted for the stability of their governments. Further, they have consistently requested the highest prices for oil and gas products. through OPEC.

\section{METHODOLOGY}

In this appraisal, we have focused on the effects of incremental pricing on the ability of an LNG project to contract with end-use customers on a long term basis (either directly or through various combinations of trunklines and 
gas distribution utilities). To be viable, an LNG project has to be able to sell the gas and to obtain financing. Further, the ability of the project to obtain financing is dependent upon securing long-term contracts with customers and upon the credit worthiness of those customers. As a result the long-term customers become crucial to the project.

Were the LNG costs allowed to be rolled-in, a potential customer, usually a trunkline, would be willing to contract on a long term basis, confident that the costs could be spread over its entire customer base and that FERC and/or the state utility regulatory commissions would grant corresponding rate increases. Were the LNG costs incrementally priced, that same potential customer would have to secure long-term contracts with potential customers of its own before committing to the LNG project. This process continues until a long term contract is established with an end-use customer. As a result, the viability of a project using conventional financing becomes dependent upon the end-use customers. Our appraisal, therefore, specifically considers the willingness of the end-use customers to contract on a long-term basis for LNG gas at incremental prices.

There are six general categories of potential end-use customers for gas from LNG projects:

1. Economic customers - purchasers who determine which fuel to use based on the lowest total cost.

2. Environmental customers - purchasers located in areas which are highly sensitive to air and water emissions.

3. Feedstock customers - purchasers who need specific chemical components found in natural gas to produce a given product.

4. Process customers - purchasers who have found that natural gas is a good way to supply heat to their manufacturing processes.

5. Electric utility customers - purchasers who need gas to fuel baseload or peaking equipment in the generation of electricity. Note: These customers may be legislated out of existence except in certain high pollution areas.

6. High-priority customers - gas distribution companies who cannot meet their requirements for their No. 1 and No. 2 priority customers.

Each of these customers will make its decision on whether to enter these long term contracts based on the importance it places on each of the following factors: cost, performance, and availability. The cost factors incorporate the contractual price of the delivered gas and any side costs related to storage and conversion to gas. The performance factors include handing requirements and economics, temperature ranges and controllability, waste/residue generation, 
purity/chemical composition, process requirements and economics, and safety requirements. The availability factors are concerned with the likelihood, real and imagined, that the supplies might be temporarily or permanently curtailed. Our estimation of the importance given to each factor by each category of potential customer becomes a key ingredient to our appraisal of the effects of a mandatory incremental price for LNG.

Against these factors for LNG, the potential customers will weigh corresponding factors for various alternatives to LNG. These alternatives are: imported oil and oil products, synthetic fuels, direct combustion of coal, electricity, and conservation. The synthetic fuels include gas and distillates from coal and shale, LPG's, and naphtha. Conservation means the lowering of total quantities of energy used.

\section{$\underline{\text { APPRAISAL }}$}

The economic customers are primarily low-priority users of gas. They can easily substitute between gas and most alternative fuels, in some cases even coal. With the cost of LNG per Btu being higher than most currently available alternatives, these potential customers will be reluctant to enter any longterm contract unless they believe that the total long-term cost of LNG will be less than that for one of or a combination of the alternatives. For the longterm cost to be less, these potential customers have to be assured (1) of a future rise* in the cost of alternatives relative to LNG and (2) of the continuing availability of LNG at the contract price. From the point of view of the economic customer, neither of these conditions are likely. First, the LNG prices in today's contracts are tied to the prices of residual and distillate oil products. Thus, under incremental pricing, little price advantage can ever be expected there. Second, if a price spread were to exist favoring LNG under these contracts, these potential customers would consider it highly unlikely that they would be allowed to benefit from it. Today's political climate is such that any situation which would yield a substantial price advantage for certain low-priority users over many other higher priority users would be halted through legislative or regulatory action. As a result, the economic customers would be unlikely to believe they could obtain a lower total long-term cost by committing themselves to an LNG contract. Thus, the incremental pricing would remove the economic customers from the potential market for LNG.

* This rise has to be significant when one takes into account the time value of money. 
The environmental customers are similar to the economic customers with the additional constraint that the alternatives must be relatively clean burning. In most cases, this means that coal and residual fuel oil would not be possible choices. Because fewer alternatives can be used, the environmental customers will place greater importance on the avallability of those alternatives. In the short-run, these potential customers will look at the availability of distillates and LPG/naphtha. In the long-run, these customers will also look at the availability of synthetic gas and distillates from coal and shale. Because of the high cost of transporting LNG relative to oil and the escalation factors built into the LNG contracts, it is likely that the long run cost of LNG will remain higher than distillates from imported oil. Further, if the synthetic fuels have prices close to what is projected now, these also will be less expensive than incrementally priced LNG over the long run. The result is that the environmental customer will also be very reluctant to committing to a long-term incrementally priced LNG contract and most of them will no longer be in the market for LNG.

The feedstock customers are those who need the chemical components of ING. These components are usually either methane or IPG's. There is a growing trend in the gas exporting countries to remove the LPG's from natural gas and sell them separately. As a result, the customers for the LPG's will be reluctant to enter into any long-term contract for ING when the components they want probably will be missing in the future.

The primary feedstock uses of methane are ammonia and methanol. The makers of fertilizer ammonia are likely to keep a relative high priority for gas because of the importance of ammonia to the Nation's food supply. Furthermore, if the extensive lobbying which is now taking place in Congress is successful, the manufacturers of ammonia may receive special legislation or rulings guaranteeing continuing access to conventional supplies of natural gas. The manufacturers of industrial amonia have less political clout; however, they can look to manufacturing ammonia from coal as a possible alternative. Present estimates of ammonia-from-coal costs indicate a high likelihood of cost competitiveness after 1990. There are some risks that these economics may not prove out, however. As a result, a small portion of ammonia.producers may choose to purchase LNG on an incremental basis to secure short-term supplies and hedge on future supplies. 
The situation for the methanol industry is similar to that of the producers of industrial amonia. However, the economics of synthetic methanol are less certain. As a result, the proportion of methanol producers forced to contract for the incremental LNG would be higher.

Unfortunately, the methanol and amonia producers contracting for incremental LNG are unlikely to fare well over the long run. Regional and system variances in costs and availability of natural gas will provide a substantial advantage for the producers who do not have to use the incrementally priced LNG. This may force the LNG users to move to a location where the gas prices are more competitive or go out of business. Obviously, this type of dislocation of indusliy would be a signiticant waste of capital and human resources.

Process customers are a combination of the economic, environmental, and feedstock customers. With these customers, the economics of their manufacturing process varies with the type of fuel used as well as the cost per Btu of that fuel. As a result, they are very sensitive to performance factors of the fuel used. If an alternative fuel is available, the total cost impact of using that fuel over the long run will be compared to that of using the incrementally priced LNG. The total cost will include effects on production rates, clean up requirements, etc. If the LNG significantly increases the cost of the end product, the alternative will be chosen. If there is no significant difference and the company is wllling to put up with occasional curtailment (a severe winter, etc.), a given process customer may be willing to enter into a long-term LNG contract, providing the customer can continue to use existing equipment and technolngy. If using LNG would require using new equipment and technology, the likelihood of entering such a contract is reduced.

Those customers who do choose to contract for incremental LNG will run the same long run risk of lowered cost competitiveness as the feedstock customers. The percentage of process customers who would refuse to contract for incremental ING compared to those who would contract for rolled-in LNG is impossible to determine because each customer has a unique set of economics. On a rough basis, we estimate that only $10 \%$ to $20 \%$ of these customers would contract for LNC if it was priced incrementally. 
The electric utility customers have the same general constraints as the environmental and economic customers. Although in the past there have been efforts to stop electric utilities from using natural gas, and currently, there are efforts to limit this consumption, some of these customers will continue to use the gas for peaking with gas turbines and occasionally as a baseload boiler fuel. In the case of the requirement for boiler fuel, the customers are highly cost conscious. As a result, the boller fuel customers would be unlikely to enter a long-term contract for the same reasons as the economic and environmental customers described previously. For peaking customers, there are fewer alternative fuels available. Because the average cost of electricity is less dependent upon the cost of peaking fuels, a utility may be more willing to pay a premium price for peaking fuel. On a practical basis, however, their alternatives are the same as those for environmental customers. Utilities are not going to enter a long-term contract for fuel which they can predict will have a higher cost and likelihood of curtailment than with alternative fuels. As a result, the utilities, unless under unusual circumstances, will be very reluctant to contract for incremental LNG on a long-term basis, and the number of electric utilities in this market will be very few.

l'he high-priority customers are those gas distribution companies who are unable to meet the needs of their No. 1 and No. 2 priority customers. These companies have no short-run alternative to natural gas. As a result, they will be forced into the long-run incremental LNG contracts. Because of the high priority of these customers, it is unlikely that end users will actually pay incremental prices. Instead, the gas distribution company will spread the incremental price over all of its high-priority end-users and the purpose of the incremental pricing will be lost.

CONCLUSIONS

Our appraisal indicates that an incremental pricing requirement on LNG would substantially reduce the number of customers who would be willing to contract for LNG on a long-term basis. This reduction will make the financing of these projects more difficult and would certainly lower the number of future projects. Our estimate is that the number of projects would be reduced to at least one-tenth of those currently projected. For those customers who were forced into the contracts because of unavailability of alternatives, there would be long-run dislocations as in the case of the process and feedstock customers, or simply high fuel bills in the case of the high-priority customers. An additional result of this policy would be greater oil and LPG imports as these are the most frequently used alternatives. 


\section{APPENDIX 1. EFFECT OF INCREMENTAL PRICING ON LNG PROJECTS}

The importation of additional quantities of LNG is planned primarily for those geographical regions which have projected gas shortages and have the most severe curtallments of gas supply. Many of these areas have already restricted gas to category 1,2 , and 3 customers. Customers in categories 4 through 9 will in all probability be denied gas until all of the category 1 ; 2 , and 3 users have been served:

We are presently faced with the issue of how to allocate additional gas made available through conservation and continuing curtailment. Should additional new high priority users be added in preference to removing curtailments of existing low priority? We believe that there is little doubt that new category 1,2, and 3 users will take precedence over restoration of curtailed low priority loads.

Let us then assume that the additional available gas supply is in the form of imported LNG. It must be allocated in accordance with the priorities established, increasing the quantities of gas available to higher priority customers first, until all are served including new high-prtority users. If this additional gas supply is offered only at a higher incremental price, very little LNG will be imported for the following reasons:

1. Existing regulatory procedures prevent a gas company from making a commitment for imported LNG unless it can show that it can market the gas without economic penalty to service customers if all of the gas is not sold.

2. The responsibility for a commitment to import LNG must be borne by the gas distribution utility. New high-priority customers are not yet in existence and existing residential customers cannot be held to an agreement made several years in advance to accept LNG when it becomes available. Thus, if additional LNG is to be made avallable to residential and most commercial customers, the distribution company must be allowed to assume responsibility for its sale. The risks in this are high when LNG is rolled-in, and would generally be unacceptable on an incremental basis.

3. The only gas user who could provide a written agreement to accept LNG is the industrial gas user who may be willing to agree to a long-term contract for LNG supply. There will, however, be few of these for the following reasons:

a. The incremental price of new LNG is likely to be higher than the equivalent price of fuel o1l and w11l not be attractive to those who can use ofl or coal.

b. Those who must use gas and may be willing to pay the premium are now eligible to receive gas under existing priorities. The current outlook for gas supply for high-priority customers appears to be assured for a number of years at least. 
There may be some industrial energy users who would be wllling to pay the premium for imported LNG if the terms of the agreement override the restrictions of Governmental control of Its energy supply; that is, if it could thus buy energy independence (except for the hazards of international polltics). This could be an attractive proposition for some industrial concerns with good foresight and large fuel conversion costs.

The experience of the El Paso 1 LNG 1mport project suggests that its cost of LNG may be lower than any other available source of natural gas, before the project is half completed. Thus, 1 is possible that an industrial fuel user could be enjoying a relatively low cost for fuel a decade from now if it contracts for imported LNG now. The high front-end costs of energy supply projects in an inflating economy assure the lowest energy supply costs if the capital expenditures are made as soon as possible.

However, from a Government policy viewpoint, the attractions of this situation create two problems:

1. If an industrial concern could contract for imported ING on terms that would insulate itself from Government priorities imposed on industrial fuels, we would create, in effect, a black market for industrial fuel supplies. A company, by paying a premium (which can be passed on to its customers), would buy an assured supply of energy independent of Government regulations.

As a practical matter we doubt that such a supply contract would be allowed to stand if a future energy crisis resulted in sizable fuel supply restrictions to others, particularly if the price of the LNG was lower than the energy options available to others at the time. This uncertainty may discourage ING importation by specific companies for their own use.

2. If such a situation is attractive to industrial fuel users, why should it be restricted to them alone by incremental pricing requirements? Permitting rolled-in pricing would allow all categories of users to benefit from additional gas supplies that in the long run may be no more expensive than other sources. The increased supply should decrease the pressure for higher energy prices generally and produce economic benefits to offset a minor saving in near-term gas rates.

Thus, it is possible that incremental gas pricing could have the opposite effect of that intended if it permits industrial concerns to obtain longterm supplies of energy that will be isolated from the general energy markets that are controlled by DOE.

All of this discussion boils down to the belief that incremental pricing will effectively prevent the importation of LNG in any significant quantities. The only end-users who are in a position to contract for it are industrial users who would pay a premium for an assured source of supply independent of use restrictions. We doubt that such assurances will be guaranteed. Thus, we foresee no significant market for LNG at incremental prices. 
The same can be said for SNG from coal or 011, as well as natural gas from Alaska, Mexico, or the Canadian Artic, if the relatively high price 16 allowed to dictate incremental pricling.

We stand to gain a full decade in development of additional supplies of both natural and synthetic gas by retaining our present gas pricing practices. The only price we pay is that of raising the average rolled-in gas price to the level of oll prices. If we wait until a world oil shortage provides an incentive to develop alternate energy supplies by forcing oil prices above those of alternate fuel supplies, we wlll have wasted the coming decade during which we should be building alternative supplies of energy in anticipation of a possible world energy shortage. One way of providing the incentive to do that is adherance to rolled-in pricing. The higher initial costs then will be absorbed by all users at a minimum cost to each, rather than requiring certain users to pay the start-up costs while everyone else benefits later on from the cash flow generated by the initial programs. 
The Council on Wage and Price Stability recently filed with the Federal Energy Regulatory Commission for permission to Intervene and to take exception to inftial decisions made by FERC in approving rolled-in pricing for recently approved LNG projects. The council expressed concern "that adoption of rolledin pricing for those expensive gas imports would needlessly increase inflationary pressures, would be inconsistent with the President's energy policy, would Impose a severe strain on the nation's balance of payments, would undercut the nation's ability to bargain with forelgn suppliers for reasonably priced additional natural gas supplies, and would frustrate the efforts now underway to adopt a more rational policy for natural gas imports." Let us examine each of these concerns in turn.

\section{Increased Inflationary Pressures}

As far as imported energy is concerned, we have the choice of importing additional natural gas or importing additional OPEC oil. There seems to be little to choose between gas and oil as far as inflationary pressures are concerned. However, the revenues generated from the importation of ING are used to a greater extent in defraying the real cost of the ownership and operation of expensive LNG tankers, liquefaction plants, and import terminals. A much lesser amount of the revenues goes to the host countries as royalties of imported oil. To this extent, the importation of natural gas in place of oil would seem to cause less inflationary pressure both domestically and worldwide than would the importation of an equivalent amount of OPEC oil.

\section{Inconsistency With the President's Energy Policy}

The President's energy plan has encouraged both additional gas imports and has generally recognized and advocated the need for higher fuel prices. The rolling-in of ING costs will raise the price of gas to all categories of users, confronting everyone with the increased cost of energy and encouraging conservation on a wider basis than would be posslble through incremental pricing which would simply discourage the importation of natural gas, leaving current low prices where they are now.

\section{Strain on the Balance of Payments}

As has been mentioned already, the importation of a given quantity of LNG strains the balance of payments no more than the importation of an equivalent amount of imported oil. 
The Nation's Abllity to Bargain With Foreign Suppliers

The United States must bargain for LNG supplies in competition with other world buyers. The Japanese are already Importing LNG into Japan at prices equivalent to the landed price of crude oll and are using. It for boller fuel as well as other utility uses. European energy buyers can afford to pay gas producers more for their gas than can the United States simply because the transportation costs to Europe are less than the transportation costs to the United States. Thus, we will always be at a disadvantage in bargaining for LNG in world markets. Our greatest advantage lies in contracting immediately so that the heavy front-end costs can be 1ncurred at lower costs than will be the case in future years. A good example is the fact that the price of LNG in the El Paso 1 LNG import program may, in a relatively short time, become the lowest priced source of gas available to the Columbia Gas System and the Consolidated Natural Gas Company.

\section{Frustration of a More Rational Policy for Natural Gas Imports}

Without knowing what a more rational import policy might be, it is difficult to comment on this expressed concern, however, it would seem to be rational to have a policy that seeks to achieve a better balance between our imports of oil and our imports of gas. Incremental pricing would not achieve this objective nearly as well as does the rolled-in pricing policy already adopted.

However, the Council on Wage and Price Stability apparently did not express concern for the basic underlying 1ssue, which is the question of whether residential and commercial users should be required to share the cost of additional gas supplies that they may not obtain directly. Our projections of the gas supply suggest that it should be possible to provide the residential and commercial and even some high-priority industrial gas markets with gas from our available natural gas supply for many years without relying upon additional imports of ING except to serve an additional segment of the industrial market. It is argued with some justification that other energy users should not be required to share the cost of this additional increment of industrial supply. This is the sole justification for incremental pricing.

However, the available supplies of natural gas are not uniformly distributed throughout the United States, and to serve the higher-priority gas markets with conventional natural gas without the importation of additional supplies of LNG or other supplemental form of gas supply will require that the existing resources be redistributed geographically. There are many injustices 
and Inequities that will be created by this redistribution. Those companies that have expended revenues collected from energy users in order to insure an adequate and continued supply of natural gas will be shortchanged by such redistribution. Those gas suppliers who have not incurred these additional expenses for added exploration efforts will obtain additional gas supplies at less than the current marginal cost of new gas supplies.

The most unfortunate aspect of incremental pricing is that it will dis: courage not only the importation of LNG, but the production of synthetic gas from coal and the development of other alternative energy sources. This will require a greater amount of redistribution of available natural gas supplies in order to serve all of the higher priority customers. There are other issues as well. The restriction of available gas supplies from industrial users will bring about the further curtailment of industrial activity in areas where gas is in short supply and will lead to the relocation of industry as well as shifting to other industrial processes that we must assume will be more expensive in adapting production or nrocesses to other less attractive fuels. We should consider the question of whether the local residential and comercial gas user will be willing to pay an additional premium to include a share of Imported LNG that would expand the availability of energy in his local community and preserve and enhance its economic development. Thus, the question is far more complex than the simple payment of a subsidy to some industrial user who should be willing to pay the full cost of the ING he would like to use,

As a practical matter, it is impossible for a gas utility to obtain commitments from a sufficient number of industrial customers to purchase LNG over the next 25 years, and without that assurance he is in a difficult position to justify to FERC that he can import ING in fixed quantities over an extended period of time without jeopardizing the investment in the required facilities. To carry incremental pricing of LNG down to the residential and commercial users is impractical for the same reason. I will not enter the discussion of the many practical problems associated with the incremental pricing of alternate gas supplies since this question can be discussed far more authoritatively by those gas utilities faced with that alternative. Instead, I would like to discuss some of the policy issues that will be raised in the future by a precedent that is set by the establishment of incremental pricing for imported LNG.

If the importation of LNG is required to be on an incremental basis to ultimate users, it raises a number of very far-reaching policy implications. 
How can the Department of Energy justify Incremental pricing for Imported ING when it requires rolled-in pricing for the importation of crude oll? To be consistent with the crude ofl equalization program, the Department of Energy should require that the increased cost of Imported ING be spread uniformly throughout the entire gas industry, not simply rolled-in with the gas supply of that company importing the ING.

Will this pricing policy also require that the production of SNG from coal be incrementally priced to the ultimate user? If so, what shall be the pricing policy for the production of synthetic oil from coal? How could a higher priced synthetic gasoline be sold incrementally in the retail gasoline market?

If natural gas from Alaska is piped into the United States at the projected prices of $\$ 3.50$ to $\$ 4.00 /$ million Btu, will this gas be priced incrementally? Will natural gas liquefied on the south coast of Alaska and transported to the West Coast by ING tankers be priced incrementally or rolled-in with other supplies? What about liquefied gas from the Canadian Arctic? It would seem that all of these alternate sources of supply must be incrementally priced along with LNG from Algeria. If so, there is serious question as to how many ultimate users would agree to take sufficient quantities of incrementally priced gas on a long-term basis sufficient to insure that the investments in these high cost supply systems can be contractually covered. It is necessary that the distribution utility be permitted to assume the risk and responsibilities for contracting for its long-term sources of supply since there are very few other energy users who can make long-term commitments for large quantities of natural gas on terms that will encourage the banking industry to loan the large sums of money necessary. 
APPENDIX 3. COST CONSIDERATIONS FOR LNG PROJECTS

Liquefaction, transportation and gasification ING projects for which applications have not been filed with the FERC have been estimated (Table 1). These costs include the cost of the ING from the point of delivery of gas Into the liquefaction plant in the exporting country to existing pipeline facilities in the United States. The costs therefore do not Include the value of the gas to the exporting country, costs of transmissions from the gas fields to the liquefaction plant, or costs of production and exploration. Also note that the liquefaction costs do not include any type of tax on the revenues generated by the exporting countries' petroleum agency. Fees on sales are generally paid by the petroleum agency to the federal and sometimes state governments of the exporting country. However, information on the extent of the fees is not available.

The costs estimates are based on the following assumptions:

1. Vaporization Costs (Including New Pipeline Costs)
a) Typical total erected plant costs using typical bare equipment costs; $25 \%$ indirect cost; $10 \%$ contingency
b) Owners charges, fees, land, startup costs at $10 \%$ of total crected plant coste
c) Allowance for Funds Used During Construction (AFDC) at $37.5 \%$ of total erected plant costs
d) Equity/Debt ratio of $25 / 75$
e) $20 \mathrm{yr}$. straight-line depreciation; $10 \%$ rate of return and $10 \%$ interest
f) Total taxes at $50 \%$
g) Typical non-capital operating expenses

2. Transportation
a) Ship size of $125,000 \mathrm{cu}$ m at a cost of $\$ 115$ million
b) $15 \%$ discounted cash flow rate of return (typical for shipping)

3. Liquefaction a) Typical total erected plant costs using typical bare
equipment costs; $41 \%$ indirect costs; $10 \%$ contingency
$b, c, d, e)$ Same as for vaporization
f) Total taxes at $0 \%$.
8) Same as for vaporization 
Table 1. ESTIMATED COSTS FOR LNG PROJECTS FOR WHICH

APPLICATIONS WITH THE FERC HAVE NOT BEEN FILED

(Liquefaction, Transportation, and Gasification Costs)

(As of 12-1-77)

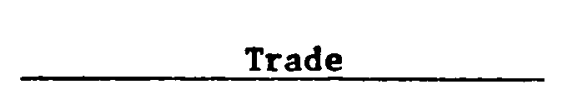

Iran - U.S. East Coast

via Suez Canal

Ch1le - U.S. West Coast

Nigeria - U.S. East Coast

Da11y Gas Volume,
$10^{6} \mathrm{CF}$
400 to 1600
400

800 to 1000

1500

1000

400 to 1000

\begin{tabular}{|c|c|c|c|}
\hline Liquefaction & Transportation & Gasification & Tota $^{\dagger}$ \\
\hline $\begin{array}{l}.50 \\
.40\end{array}$ & $\begin{array}{l}1.85 \\
1.85\end{array}$ & $\begin{array}{l}.44 \\
.38\end{array}$ & $\begin{array}{l}2.79 \\
2.63\end{array}$ \\
\hline .50 & .85 & .44 & 1.79 \\
\hline $\begin{array}{l}.44 \\
.42\end{array}$ & $\begin{array}{l}1.15 \\
1.15\end{array}$ & $\begin{array}{l}.41 \\
.40\end{array}$ & $\begin{array}{l}2.00 \\
1.97\end{array}$ \\
\hline $.40^{+t}$ & .80 & .38 & 1.58 \\
\hline $.42^{t+}$ & 1.00 & .40 & 1.82 \\
\hline $\begin{array}{l}.50 \\
.42\end{array}$ & $\begin{array}{r}.55 \\
.55\end{array}$ & $\begin{array}{l}.44 \\
.40\end{array}$ & $\begin{array}{l}1.49 \\
1.37\end{array}$ \\
\hline
\end{tabular}

* Costs are 1n 1st Quarter 1977 dollars.

${ }^{+}$Not including cast of gas at wellhead or exporting country taxes.

t+ Because costs are typical, the costs of 11quefaction facility construction is undoubtedly underestimated for harsh environment above. Arctic circle. 
COOPERATIVE ARAB/ISRAELI ENERGY PROGRAMS BASED ON NATURAL GAS 


\section{EXECUTIVE SUMMARY}

Introduction

The intent of this paper is to provide DOE with an overview of the technological and economic aspects of cooperative Arab/Israeli programs based on natural gas resources in Egypt and Israel. To accomplish this the paper discusses the natural gas technology which could be utilized in possible cooperative programs between the Arabs and Israelis, the current situation in regard to natural gas resources and utilization, potential regional benefits to be derived from cooperative programs, and major constraining factors to program developmenl and natural gas utilization.

\section{Cooperative Ventures Involving Natural Gas}

of the multitude of possible options for utilizing natural gas, the preferred alternatives for regional cooperation can be classified into two primary categories: Chemical Feedstocks and Fuel Uses. These two categories are each then comprised of two subcategories: Regional Consumption and Export.

Four types of ventures appear to have the best potential in gaining support and promoting regional bencfits. These are -

- Development and use of a regional pipeline network to provide natural gas as a fuel in the residential, commercial, industrial, and power generation sectors

- Construction and operation facilities to export natural gas to Europe as LNG or by means of a pipeline system that would join with the transMediterranean pipeline

- Use natural gas and natural gas liquids to produce chemical feedstocks which would form the basis for regional industrial development including the manufacture of finished products

- Produce from natural gas and natural gas liquids chemical feedstocks and liquid fuels for export.

It may be possible to undertake more than one of these ventures simultaneously depending predominately on resource availability and markets.

It will probably take a minimum of 10 years to bring any of these alternatives to fruition. This does not consider that there are existing facilities for utilizing natural gas in Egypt and Israel for petrochemical and fertilizer manufacturing, but allows only for the development of new resources and a more intensive utilization industry. 
The order-of-magnitude investment requirements are approximately $\$ 500$ million to $\$ 1.0$ billion except for the fuel export alternative which would be approximately $\$ 500$ million to $\$ 1.5$ b1lifon in 1978 dollars.

The skill levels involved cover the entire range from senior professional engineers and administrators to office workers and laborers for all the programs. The highest skill levels would be required for the petrochemical alternatives (particularly if finished consumer products are included) and the LNG export option. The highest concentration of both skilled and unskilled workers would be associated with design and construction.

While no attempt has been made to provide a quantitative breakdown of labor categories, an order-of-magnitude estimate indicates that the total employment potential for the regional fuel delivery option is 20,000; for the fuel export option, 500-1000; and for the petrochemical complex a range which could extend to 20,000. These estimates do not include those workers required for the secondary services (schools, police, shops, etc.) generated.

A further consideration in regard to regional benefits as a result of cooperative programs would be an increased need for technical and liberal arts colleges to provide trained staff for these industries.

\section{Constraining Factors}

Resource is the most significant constraining factor. Currently, Egypt's natural gas reserves are estimated at 4.5 trillion CF. This estimate includes the Nile Delta basin, Western Desert, and the Gulf of Suez. It does not include either the Red Sea or the north Sinai areas even though gas wells are currently producing in those areas. Israeli reserves of natural gas are insignificant.

Depending on the type of cooperative project initiatĕd, world market factors could play an important role. For example, the petrochemical market appears to be in a state of over capacity between now and the mid-1980's. This could improve from a seller's point of view after this time making a cooperative effort into petrochemicals attractive, particularly in view of the estimated 10-year implementation time required. However, the Saudis have indicated a desire to greatly increase their share of the world petrochemical market. If this is carried through, it would cause problems for the cooperative programs 
Involving petrochemicals. On the other hand, considering the labor problems professed by the Saudis, perhaps they could be convinced of the advantages of supplying the natural gas to the regional program. This would then solve the labor problems for the Saudis and the potential resource problem for the cooperative programs. 


\section{INTRODUCTION}

This concept paper discusses in general natural gas technology which could be ut1lized in possible cooperative programs between the Arabs and Israelis, the current situation in regard to natural gas resources and utilization, potential regional benefits to be derived from cooperative programs, and major constraining factors to program development and natural gas utilization.

\section{Objective}

The objective of this paper is to provide DOE with an overview of the technological and economic aspects of cooperative Arab/Israeli programs to utilize regional natural gas resources. The political developments in the Middle East or any conditions a negotiated peace plan is likely to contain have been eliminated from this discussion to avoid confusion of political possibilities with real economic and technological possibilities for natural gas utilization. The paper will focus on Egypt, Israel (including Gaza and Sinai), and include the Jordan (and the West Bank) by implication.

Natural Gas Technology Options

There are many options to consider for cooperative programs relating to the use of natural gas resources. Given adequate supplies of natural gas, Figure 1 illustrates these options. The resulting alternatives can be classified into two primary categories: Chemical Feedstocks and Fuel lises. These two categories are each then comprised of two subcategories: Regional Consumption and Export.

For all alternatives the technologies involved include drilling and well production, gas liquids stripping, pipelining, and various end-use alternatives. For some alternatives it could include natural gas liquefaction facilities, ocean shipping, and submarine pipelining. None of these technologies require further research or development to make them viable, and all are commercially available. 


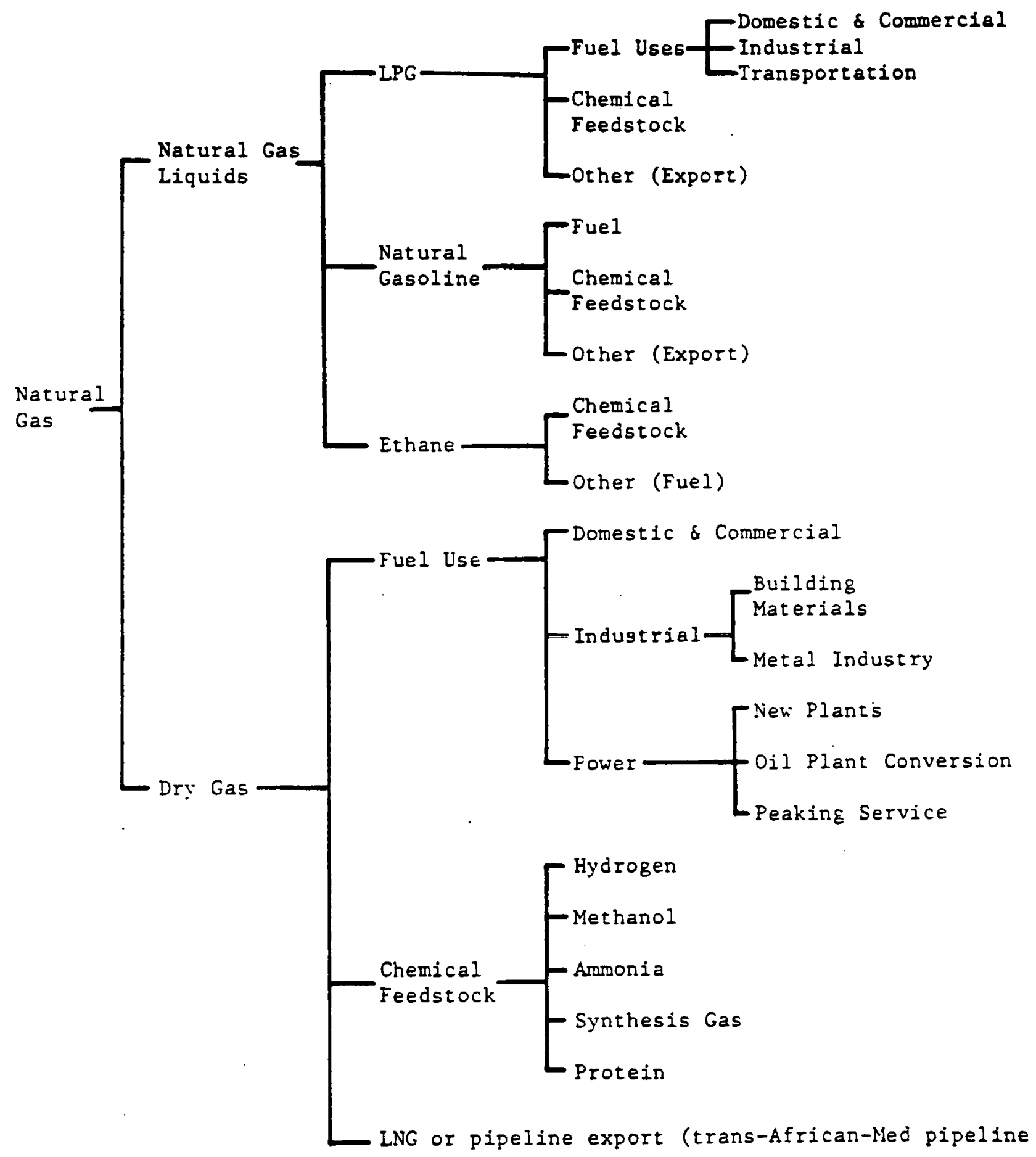

Figure 1. OPTIONS AVAILABLE FOR THE UTILIZATION OF NATLRAL GAS RESOURCES 
Possible Programs

We feel that there are four types of ventures which could be considered for Arab/Israel cooperation. These are -

- Development and use of a reglonal pipeline network to provide natural gas as a fuel in the residential, commercial, industrial and power generation sectors

- Construction and operation of facilities to export natural gas to. Europe as LNG or by means of a pipeline system that would join with the transMediterranean pipeline

- Use natural gas and natural gas liquids to produce chemical feedstocks which would form the basis for regional industrial development including the manufacture of finished products

- Produce from natural gas and natural gas liquids chemical feedstocks and 11quid fuels for export.

It should be borne in mind that it would be possible to undertake more than one of these ventures simultaneously. However, it is unlikely that a commitment to the first would allow the second to also be undertaken. Likewise, the third and fourth are not likely to be undertaken together. It is conceivable that some combination of the first and third or fourth, and the second with the third or fourth, would be possible.

The first venture would call for the development of a natural gas pipeline and distribution system similar in concept to that in the U.S. It would first necessitate the development of potential reserves (or a guarantee of gas supplies from the Saudis, for example) adequate enough to support on a long-term (50 years plus) basis such an industry: Next, a pipeline transmissịon and distribution system has to be constructed to move the gas from the flelds to. the points of consumption. This calls for two distinct systems: one operating on a point-to-point basis with relatively large diameter, high pressure pipelines; the other an interconnected pipeline grid with smaller diameter pipes and lower pressures. Typically for the U.S., a transmission line will be 24 inches to 36 inches in diameter and operated at 600 to 900 psia with either radial or axial compressors driven by reciprocating engines or turbines. Distribution networks operate at about 60 psia for the newer systems (as low as 5 psia in the older systems) and with pipes that are 2 to 6 inches in diameter, with services to end-users from 1-1/2 inches to $3 / 4$ inches in diameter and household pressures of $1 / 4$ psia. 
Devices capable of utilizing natural gas will also be necessary. This should cover a full range of sizes and types for the residential, commercial, and industrial sectors.

This system could then supply natural gas to the major metropolitan areas of Egypt, Israel, and Jordan, while promoting and/or supplying industrial and commercial operations at intermediate distribution points.

The second venture would require only the first part of the previous program. It would involve the development of the gas reserves and the pipeline transportation system. At this point, the choice could be made to export the natural gas as a liquid in the form of LNG or as a gas to Europe, for example, via a pipeline system potentially across the Mediterranean Sea.

The LNG alternative could involve a liquefaction and storage facility of the coast of Egypt or the Sinai. This would be connected to the natural gas fields by pipelines. Such a venture would also involve the construction and operation of cryogenic tankers for transporting the LNG.

The pipeline export alternative would have to, it seems, involve the participation of all the North African Arab states. This seems necessary because the most desirable point to cross the Mediterranean Sea would be from Tunisia to Sicily and then to southern Italy. In fact, this crossing has already been seriously discussed and planned. A second point is the need to have enough natural gas to ship to make such a venture worthwhile.

The next two alternatives involve the use of natural gas and its liquids for chemical manufacture. The difference between the two lies in the development of one for regional use (with a potential for the export of finished products) and the other solely for exporting the chemical commodities. Table 1 presents a partial list of the candidate petrochemicals, intermediates, and fuels that could be produced in a petrochemical complex based on natural gas.

Such an industry will also necessitate a natural gas gathering and transmission system to connect the fields to the petrochemical sites. Gas liquids stripping plants to recover the natural gasolines and LPG will also be needed. As such, it would be possible to use these liquids and ethane recovered from the natural gas to feed the petrochemical industry while still maintaining the dry natural gas for regional fuel use. 
The worth of such a combined program will not only depend upon the economics, but also on the composition of the natural gas. If the gas is rich in heavy hydrocarbons (as is normal with gas assoclated with oil production) it may be possible. If the gas is lean in those heavier hydrocarbons, it is unlikely that a combination petrochemical/fuel program would be feasible.

Table 1. CANDIDATE PETROCHEMICAIS, INTERMEDIATES, AND FUELS

$\begin{array}{ll}\text { Acetone } & \text { Propylene } \\ \text { Acrylonitrile } & \text { 2-4 TDI } \\ \text { ABS } & \text { Ethylene } \\ \text { Benzene } & \text { Acetic Acid } \\ \text { Cumene } & \text { Acetylene } \\ \text { Cyclohexane } & \text { Jet Fuel } \\ \text { Ethylene Glycol } & \text { LPG } \\ \text { Ethylene Oxide } & \text { Urea } \\ \text { Perchlorethylene } & \text { Ammonia } \\ \text { Phenol } & \text { Caustic Soda } \\ \text { Polyethylene H.D. } & \text { Helium } \\ \text { Polyethylene L.D. } & \text { Carbon Dioxide } \\ \text { Polyestyrene } & \text { Methyl Alcohol (Methanol) } \\ \text { Polyestyrene (High Purity) } & \text { Xylene } \\ \text { SBR } & \text { Bisphenol A } \\ \text { Styrene } & \end{array}$

A joint Arab/Israeli industrial development center could be established in the northern Sinai region. The center (The Sinai Industriplex) would utilize natural gas and natural gas liquids to upgrade basic raw materials to semi-finished or finished products. Raw materials for ferrous and non-ferrous metals product, cement manufacture, and other basic industry could be drawn from the Arab countries bordering the Sinai region to both the east and west. Dry natural gas would be converted to hydrogen for direct iron ore reduction; to ammonia and derived nitrogenous fertilizers for regional use and possibly export; to synthesis gas and upgraded to alcohols and other oxygenated products. Natural gas liquids would be converted to petrochemicals such as plastics, detergents, etc. Natural gas would be used as a process fuel and for power generation throughout the complex. Surplus electrical power could be sold to the regional grid. 
Ready access to a deep water port would reduce transportation costs. Under present conditions this would limit locations to the Port Said region on the west or extreme northeastern Sinai. However, if a new port development program were included, the site selection could be more flexible.

Natural gas and natural gas liquids for the complex would be supflied from either the regional fields, including those of the Red Sea area (which are still to be developed) or the vast resources of the Saudi Peninsula fields. This latter alternative could provide a ready outlet for natural gas, which presently is being flared. Assuming a land-based pipeline could be built across Israeli territory, this alternative of moving the raw materials to the available labor pool could be more economical and create fewer social stresses than building manufacturing plants near the raw material source and relocating the labor force.

As a longer term aspect of this alternative, the labor and value added component of natural gas derived petrochemicals, such as plastics, could be maximized by converting the basic raw materials and intermediates to finished consumer products. The additional value derived from producing finished products from the intermediates is illustrated in Figure 2. The benefits would be twofold. More local jobs would be created and foreign exchange credits now expended for each consumer product would be eliminated. However, a strong marketing capability perhaps supplemented by special tariff treatment would be needed to assure the regionally produced products were competitive with imported goods. More highly skilled workers and a higher level of technical competence is usually required to produce the finished consumer products so the potential for sharing of technology and training capabilities would also be increased.

The timing of any of these four alternatives is highly speculative. However, the time lag will be entirely comprised of the time required to verify' the resources and construct the facilities. There will be no time required for research or the development of technological advances. Table 2 presents an estimate of the possible time needed from conception to having the facilities on-stream. In the case of the regional natural gas fuel distribution system, portions could be implemented at an early stage. However, as was the case in the U.S., full development of this network will take 20 to 30 years or more; and for that matter, as long as the resource allows and the demand increases it continues to grow. As can be seen from Table 2, we do not expect 
Table 2. ESTIMATES OF THE TIME FOR IMPLEMFNTATION OF COOPERATIVE PROGRAMS USING NATURAL GAS RESOURCES

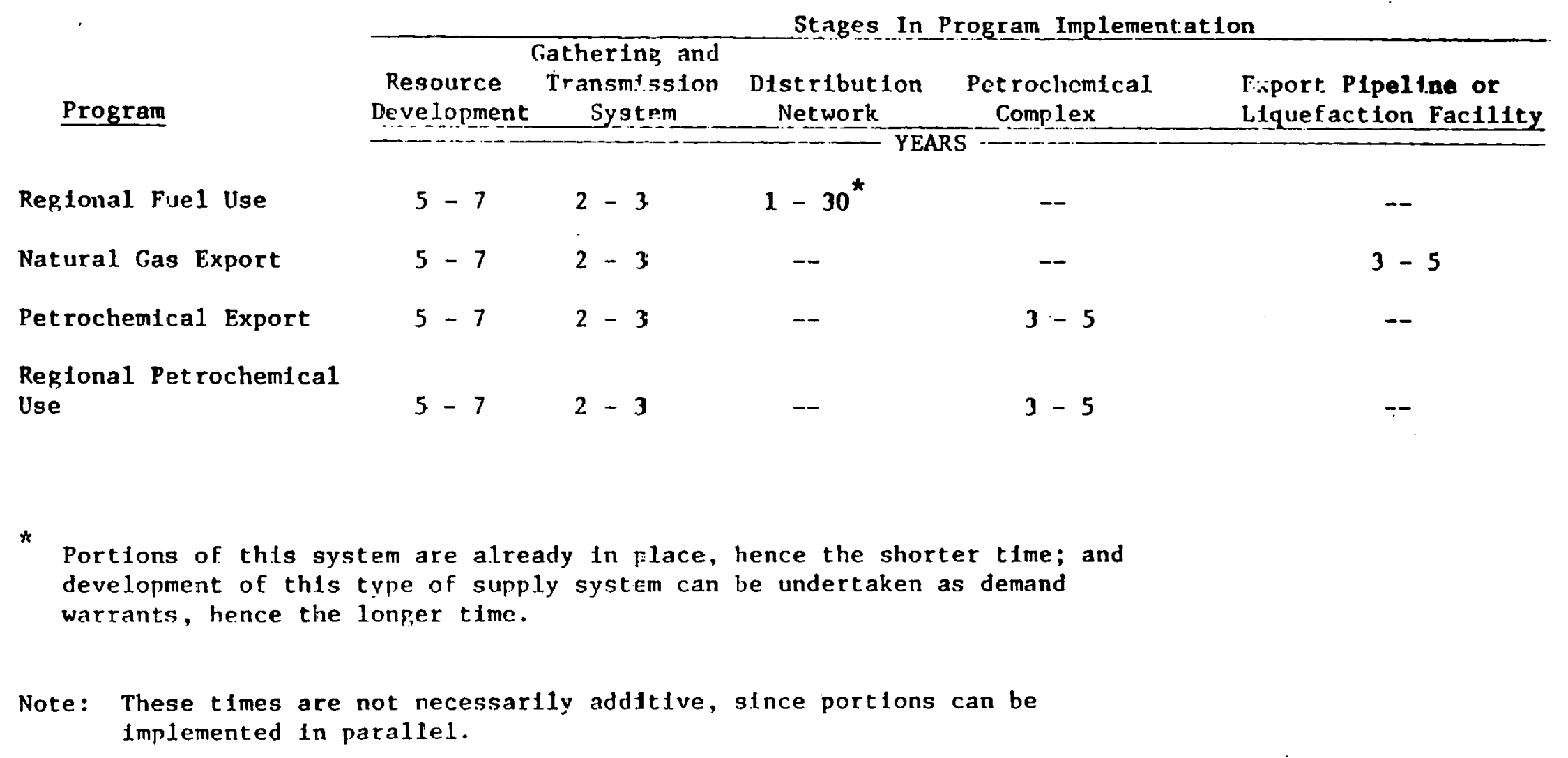


MONOMERS and INTERMEDIATES

$16 \times$

POLYMERS and RESINS

$100 x$<smiles>CCC</smiles>

FINISHED PRODUCTS

Figure 2. CLMLATIVE VAIUE OF PETROCHEMICALS SHOWING INCREASE FROM RAW MATERIAIS TO FINISHED PRODUCT

that any program could be on-stream in much less than 10 years; although each of the projects could be started immediately. Further, except for the regional fuel use alternative none of the options have included the time required to develop a transportation system. In the case of ING export, this will involve cryogenic tankers and for the petrochemicals either tankers, freighters, or ground transport (rail cars or trucks).

The duration of any of these projects should be unlimited as long as the resource is available. This will depend on the physical size of the resource and on the rate of consumption. (The resource size will be discussed below.)

The order-of-magnitude cost estimates for the four alternatives do not seem to be too dissimilar from each other. Table 3 presents an estimate of the investment requirements by major project component. Except for the fuel export alternative involving ING which is $\$ 500$ million to $\$ 1.5$ billion, the alternatives all require approximately $\$ 500$ million to $\$ 1$ billion in 1978 dollars. The point to be made here is that any of these programs, if undertaken, will require hundreds of thousands of dollars.

The skill levels involved run the gamut from senior professional engineers and administrators to office workers and laborers for all the programs. The highest skill levels would be required for the petrochemical alternatives (particularly if finished consumer products are included) and the ING export option. The highest concentration of boch skilled and unskilled would be associated with design and construction. Only the regional fuel use option would 
Table 3. ORDER-OF-MAGNITUDE ESTIMATE OF INVESTIMENT REQUIRED FOR NATURAL GAS PROGRAMS

\begin{tabular}{|c|c|c|c|c|c|c|c|c|}
\hline Program & $\begin{array}{c}\text { Resource } \\
\text { Development }\end{array}$ & $\begin{array}{l}\text { Gathering and } \\
\text { Transmission }\end{array}$ & $\begin{array}{l}\text { Distribution } \\
\text { System }\end{array}$ & $\begin{array}{l}\text { Pet rochemfical } \\
\text { Complex }\end{array}$ & Export & PIpeline & e/Lique & efaction ${ }^{\dagger}$ \\
\hline Regional Fuel Use & $100-500$ & $100-150$ & $30-50$ & -- & & -- & l & -- \\
\hline Natural Gas Fxport & $100-500$ & $75-125$ & -- & -- & & $50-100$ & / 375- & -750 \\
\hline Petrochemfcal Fxport & $100-500$ & $75-125$ & -- & $200-400$ & & -- & I & -- \\
\hline $\begin{array}{l}\text { Reglonal Petro- } \\
\text { chemfcal Use }\end{array}$ & $100-500$ & $75-125$ & -- & $200-400$ & & -- & I & -- \\
\hline
\end{tabular}


employ a constant construction/repair force for the pipeline transmission/ distribution systems. This alternative may also provide the widest spread of skills of any of the alternatives except for the petrochemical/finished products combination.

\section{Current Situation}

Within the scope of this paper, it was not possible to separate the use of natural gas in either Egypt or Israel into fuel and feedstock uses. It appears, however, that virtually no natural gas industry for residential/ commercial consumption exists in either country (less than $0.13 \%$ may go to this application in Egypt).

The overall use of gas has grown in Egypt at a rate better than $100 \% /$ year and had grown to 45.61 trillion Btu by 1976. No comparable figures on Israel have been located (1973 consumption was 4.2 trillion Btu down from 10.5 trillion Btu in 1970), but it seems reasonable that its industrial activity would not have been less than Egypt's from 1973 to the present. Although hampering, Israel's industrial use of gas would be its resource base, which is much more restricted than Egypt's. Israel's natural gas appears to come predominantly from the occupied areas of the north Sinai and Gaza.

Egypt has now only two natural gas pipelines. These are shown in Figure 2. One links Abu Gharadiq in the western desert to Helwan in the area of Cairo with a proposed link to Suez. The other from Abu-Madi in the Nile Delta to Tanta.

Israel currently supplies natural gas for industrial use to Beersheba. Gas for this application comes from Zohar with new production to come from near Rafah west of the Egyptian border in the Gaza strip. Wildcat wells are being drilled and oil shows have been obtained along the coast from Gaza to Tel Aviv. Further information on the extent of the Israeli use of natural gas was not obtained.

Petrochemical activities seem h1gh in both countries. Egypt has announced at least three projects for the manufacture of polyvinyl chloride and polyethylene, paraxylene and fertilizer (ammonia and urea). Israel has at least three projects underway for ammonia, urea and melamine; vinyl chloride; and aromatics. All these facilities are due to be on-stream by 1979. In Israel 


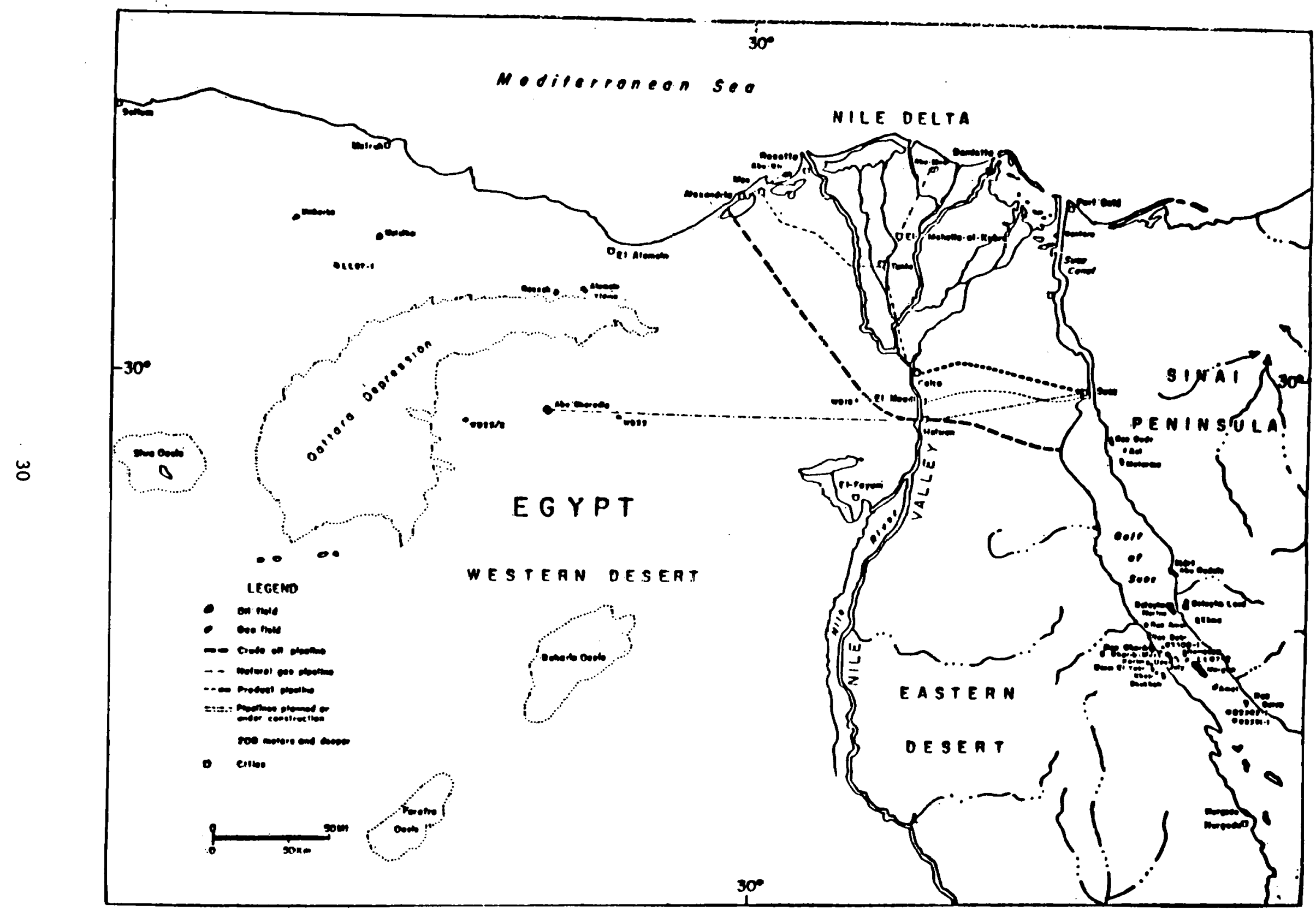

Figure 2: LOCATION OF OIL AND GAS FIELDS AND PIPELINES (1977) IN RELATION TO GEOGRAPHIC, PROVINCES IN EGYPT (Source:, USGS) 
these facilities appear to be being built by Israeli concerns while in Egypt the plants are belng constructed by foreigo flrms (two by Foster Wheeler, Itallana).

The current status of the reglonal avallability of natural gas is uncertain at best. Egypt has no really large oil or gas flelds. Estimates of gas reserves are currently at 4.5 trillion CF for 1977. This estimate breaks down in terms of area as follows -

$\begin{array}{lr}\text { Area } & \text { Reserve Estimate } \\ \text { Nile Delta Basin } & 1.5-2.5 \\ \text { Western Desert } & 1.0-1.5 \\ \text { Gulf of Suez } & 0.0-0.5\end{array}$

No estimates have yet been made for the north Sinai nor the Red Sea areas even though gas wells are currently producing. Estimates of ultimate recoverable reserves have not been located, and it is uncertain whether any exist.

Israeli reserves of natural gas are also not known for certain. One estimate puts natural gas reserves as of January 1, 1977, at 20 billion CF. For the most part, wildcatting operations have only begun recently, and the major finds have been in the occupled areas of north Sinai and the Gaza strip. For example, the Sadot field in the Gaza Strip which will be used to supply Beersheba is estimated to have reserves of 34 billion CF. This field alone more than doubles the estimated reserves in 1977.

As a potential fall back position for the programs proposed here, in case natural gas and liquids do not materialize, it may be possible to ship gas from the Saudi Arabian peninsula, thus providing the reserve base necessary for the development of a natural gas-based petrochemical or fuel delivery system. As has been mentioned previously, associated gas from these fields could be transported across Istaeli territory to a point on the Mediterranean Sea for a petrochemical complex or supplied into a regional natural gas supply network.

\section{Benefits of Reglonal Cooperation}

Without much doubt efforts between the Arabs and Israelis in the EgyptIstael-Jordan area that result in increased supplies of oil and gas will stimulate economic growth and cooperation in the region. While both Egypt and 
Israel experlenced a steady decline in gas production in the 1970-73 period, Egypt at least has seen a tremendous jump in production since that time. Israel on the other hand, has apparently only a single, small source of oil and gas entirely within 1ts borders at the Helez field near Ashdod. It still is planning on ut1lizing some ofl and gas from occupled areas of the Sinal, but expansion of this use would certainly be enhanced by a cooperative effort to develop these resources.

Of the possible cooperative programs the least beneficial in the long term would be the export programs. While they would employ both highly skilled and non-skilled labor in the development phases, the prospects for long-term employment of many workers is not likely. The total employment potential for these operations would be from 500 to 1000 including technical, clerical, and administrative staffs. This estimate does not include the manpower required for exploration and drilling.

For the concept involving natural gas distribution to the major metropolitan areas within the region, we estimate that about one employee per 150 customers is required. This is based on a North African country's utility system at roughly the next stage beyond what is currently available in the region. This means that for an estimated 3 million gas customers in Egypt, Israel, and Jordan that on an order-of-magnitude basis 20,000 people would be employed.

An estimate of the total employment potential for the petrochemical option is even more speculative, since it depends on the total size, the types of plants, the capacity and number of each. Figure 3 presents a much simpilfied representation of a petrochemical complex based on natural gas with a range of the number of plant workers required. It shows a natural gas stream coming into a shipping plant where the subsequent components are used to make primary and intermediate chemical products. This schematic shows 16 possible plants and, for a typical range of plant size, an estimate of the number of workers associated with the gas transmission facilities and the complex. This estimate sets the number at an order-of-magnitude of 1000 workers. Another roughly 1000 workers in an administrative support capacity would also be required. This, however, is a fraction of the number which could be employed considering the additional intermediates that can be made and allowing for multiple plants. Thus, a work force of 20,000 for this option also seems possible. 


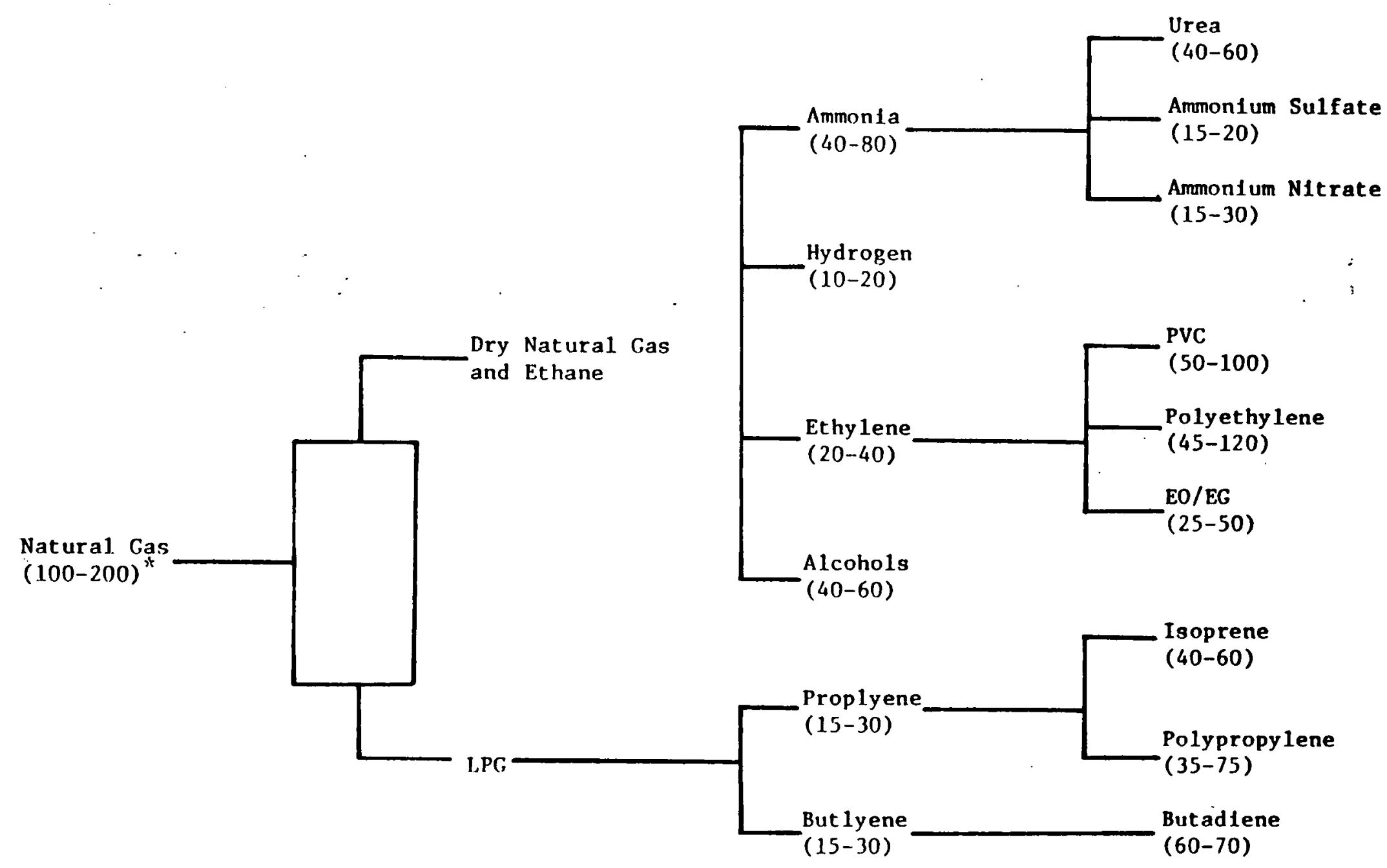

* Includes acid-gas removal, compressor stations, and the liquids stripping facility.

Figure 3. SIMPLIFIED NATUPAL GAS BASED. PETROCHEMICAL COMPLEX WITH ESTIMATES OF STAFF REQUIREMENTS EXCLUSIVE OF ADMINSTRATIVE WORKERS 
If this is extended to include the finlshed products, the expansion of delivery systems, the requirement for secondary support facilities (schools, police, fire department, shops, etc.), the potential employment opportunities greatly increase.

The requirement for technical and liberal arts colleges to provide trained staff for these industries must also be included in the potential for manpower development and the overall opportunities afforded the region through those types of cooperative programs.

\section{Constraining Factors}

Resources will certainly be the most significant constraining factor particularly if there is no way to make use of Saudi Arabian reserves of natural gas. Depending on the type of cooperative project initiated, world market factors could play an important role. For example, the petrochemical market appears to be in a state of over capacity between now and the mid-1980's. This could improve from a sellers' viewpoint in the late-1980's to early-1990's making a cooperative effort into petrochemicals attractive. However, the Saudis have indicated a desire to greatly increase their share of the world petrochemical market through the use of their associated natural gas. If this is carried through, it would be a dual blow to a regional Arab/Israeli project. Skilled labor will be a problem, however, for the Saudis in implementing this program. This labor constraint may consequently create an advantage for the Arab/Israeli project.

The basis for either a regional fuel delivery system or petrochemical industry seem to be in place and with prudent planning, there would seem to be no problem in establishing and/or strengthening existing organizations. 
AN EXAMINATION OF FEA REGIONS WITH REGARD

TO THE NATURAI GAS POLICY ACT OF 1978 


\section{INTRODUCTION}

The Individual regions of the United States have developed a dependency on the different forms of primary energy to a varying degree. Factors, such as the regional resource base (of fuel and non-fuel commodities), availability of natural transportation (i.e., waterways and later the development of railways, highways, and pipeline networks) within and between regions, and growth of the industrial, residential, and commercial sectors, are all combined to shape the current regional energy profiles. Because of these peculiarities, specific pieces of federal energy legislation, such as the Natural Gas Policy Act of 1978 (NGPA), will have a varying impact in the individual regions of the country. Although this point appears self-evident, the complexity and interdependency of the factors involved make quantification of the potential effects difficult at best. With this in mind, a profile of the Federal Energy Administration (FEA) Region 5 was constructed such that when data are available, the impacts of the NGPA can be quantified. Region 5 is composed of Illinois, Indiana, Michigan, Minnesota, and Wisconsin. A map of all ten FEA regions and a listing of states within each region are shown in Figures 1 and 2 , respectively. 


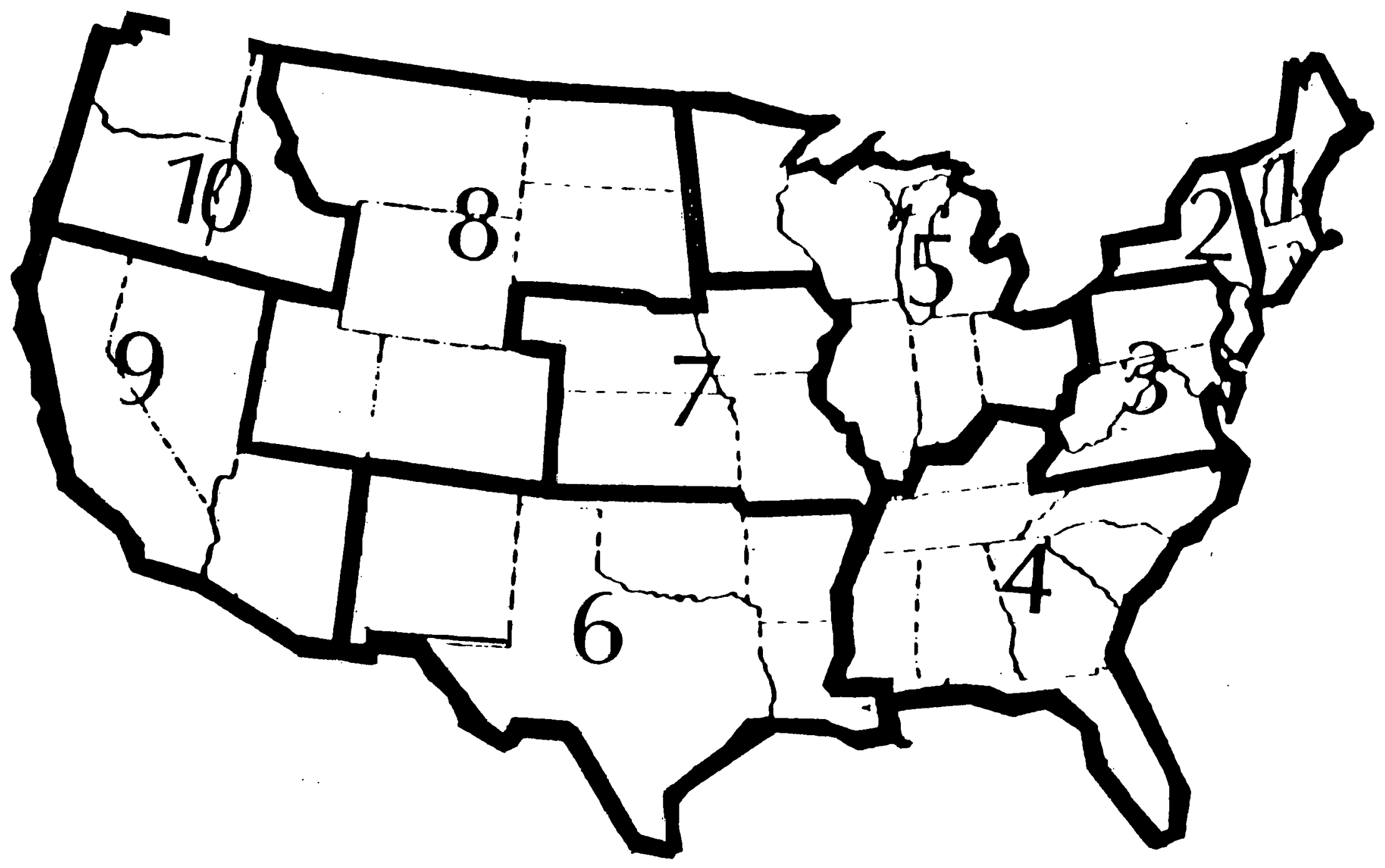

Figure 1: FEDERAL ENERGY ADMINISTRATION REGIONS IN THE CONTIGUOUS U.S. 
Region

1
-2
3
4
5
6
7
8
9
10

\section{Stetes}

CT, LE, MA, NTH, RI, VT

$\mathrm{NJ}, \mathrm{NY}, \mathrm{PR}^{*}, \nabla I^{*}$

$D E, K D, P A, V A, W V, D C$

$A L, G A, F L, M S, N C, S C, T N, K Y$

II, IN, OH, MI, WI, MN

$A R, L A, O R, T X, N M$

IA, KS, MO, NE

$C O, U T, W Y, M T, N D, S D$

$A Z, C A, N V, \mathrm{HI}^{*}$

$A R, I D, O R, W A$

*Excluded from reglonal energy tables and analysis.

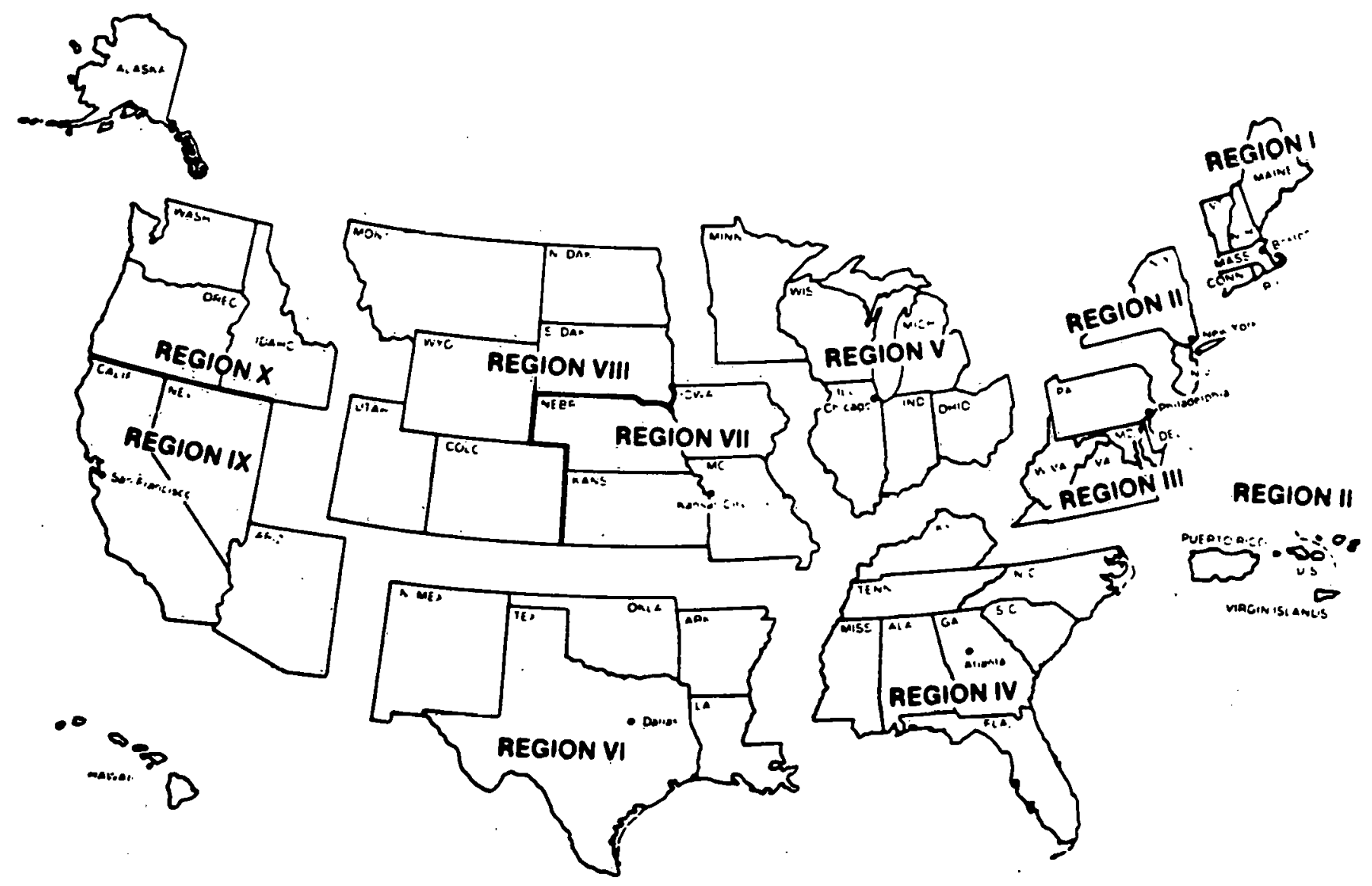

FIguire 2. FEDERAL ENERGY ADMINISTRATION REGIONS 


\section{COMPARISON OF REGION 5 TO THE UNITED STATES}

According to 1975 data, selected to correspond with the latest available, detailed, company-specific natural gas flow data, FEA Region 5 ranked first In total energy consumption with $15,459 \times 10^{12}$ Btu of primary energy being consumed by all sectors. Tables 1 through 5 display the energy consumption profiles of the ten FEA regions (two regions per individual table). Consumption data for Hawai, Puerto Rico and the Virgin Islands are not included in their respective regional, or United States, summary tables. Each table presents the energy equivalent quantities of five selected primary energy sources (coal, oil, natural gas [NG], nuclear, and hydro) consumed by five sectors of the economy (residential, commercial, industrial, transportation, and electric utility). Totals are presented for each consuming sector, each fuel type, and each primary energy source exclusive of transportation uses. The electric utility sector is, of course, the sole consumer of nuclear and hydro power for electricity generation. Because primary energy consumption is the concern of this portion of the analysis, the purchase of this electric power (a secondary energy source) is not accounted for in the other sectors.

On the basis of the proportion of each energy type consumed in the individual sectors, Region 5 compares to the United States (sumarized in Table 6) as follows:

- Residential Sector. The primary energy consumption mix in this sector, on the whole, corresponds to the national averages, with the percent of coal usage approximately equivalent, a lower dependency on oil, and a higher dependency on natural gas. On an energy equivalent basis, $1.9 \%$ of the energy consumed in the residential sector is derived from coal, $21.37 \%$ from oil, and $76.73 \%$ from natural gas. This compares with national percentages of $1.38,27.34$, and $71.28 \%$, respectively.

- Commercial Sector. Again, the proportion of coal in the Region 5 energy mix, $1.66 \%$, is comparable to the national average of $1.08 \%$. Oil plays a lesser role in the region, $42.08 \%$ versus $53.06 \%$ nationally, and natural gas a greater role, $56.26 \%$ compared with $45.85 \%$ for the United States as a whole.

- Industrial Sector. Coal provides $38.04 \%$ of the industrial energy consumed in Region 5, oil $21.08 \%$, and natural gas $40.88 \%$. This compares with national percentages of $19.69 \%$ for coal, $25.16 \%$ for oil, and $55.15 \%$ for natural gas. Metallurgical coal consumption in the Region 6 percentages may tend to overstate coal's relative importance and understate the importance of natural gas in industry. 
Táble 1. TOTAL ENERGY CONSUMPTION ( $10^{12}$ Btu), REGION: 1

\begin{tabular}{|c|c|c|c|c|c|c|c|}
\hline \multirow[b]{2}{*}{ Fue1 } & \multicolumn{7}{|c|}{ Sector } \\
\hline & Res1dent 1al & Commerclal & Industrial & Transportation & Electric Utillty & Total & $\begin{array}{l}\text { Total Less } \\
\text { Transportation } \\
\end{array}$ \\
\hline Coal & .4 & .3 & 5.6 & -- & 34.6 & 40.9 & 40.9 \\
\hline 011 & 363.1 & 404.1 & 159.8 & 651.8 & 442.8 & 2021.6 & 1369.8 \\
\hline NG & 158 & 64.5 & 69.3 & 1.4 & 2.1 & 295.3 & 293.9 \\
\hline Nuclear & -- & -- & -- & -- & 175.4 & 175.4 & 175.4 \\
\hline Hydro & -- & -- & -- & - & 36.2 & 36.2 & 36.2 \\
\hline Totals & 521.5 & 468.9 & 234.7 & 653.2 & 691.1 & 2569.4 & 1916.2 \\
\hline
\end{tabular}

TOTAL ENERGY CONSUMPTION $\left(10^{12}\right.$ Btu), REGION: 2

Sector

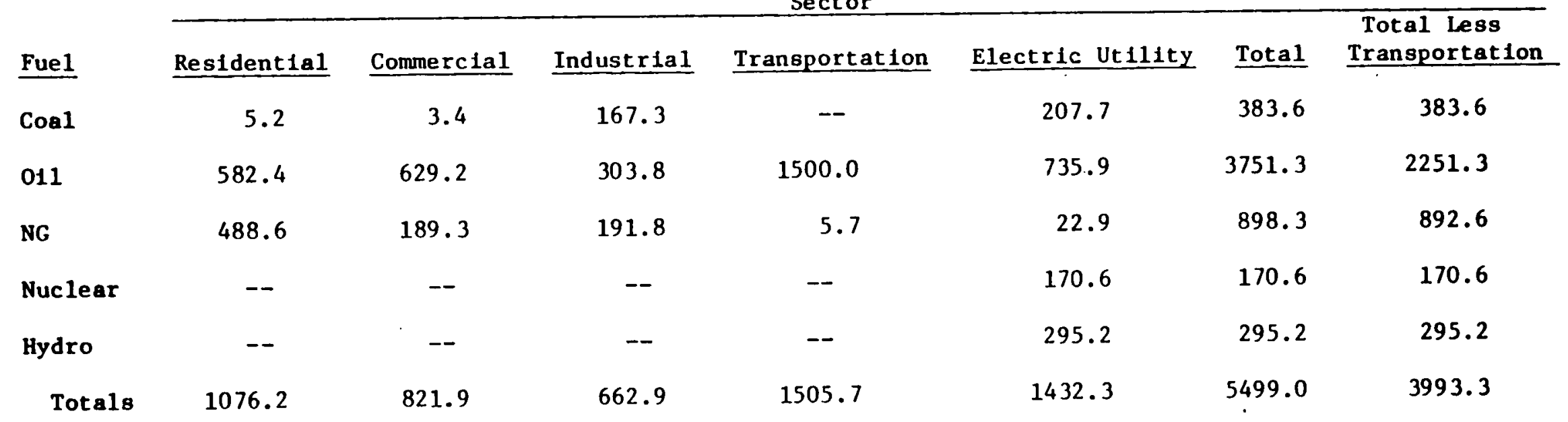


Table 2. TOTAL ENERGY CONSLMPTION ( $10^{12}$ Btu), REGION: 3

Sector

\begin{tabular}{|c|c|c|c|c|c|c|c|}
\hline Fue 1 & Resident1al & Commerc1a1 & Industrial & Transportation & Electric Utility & Tota1 & $\begin{array}{l}\text { Total Less } \\
\text { Transportation }\end{array}$ \\
\hline Coa1 & 34.6 & 21.5 & 1214.7 & -- & 1691.6 & 2962.4 & 2962.4 \\
\hline 011 & 304.6 & 336.8 & 429.4 & 1696.5 & 440.0 & 3207.3 & 1510.8 \\
\hline NG & .500 .8 & 205.7 & 522.4 & 41.3 & 4.4 & 1274.6 & 1233.3 \\
\hline Nuclear & -- & - & - & -- & 306.9 & 306.9 & 306.9 \\
\hline Hydro & -- & - & - & -- & 58.4 & 58.4 & 58.4 \\
\hline Totals & 840.0 & 564.0 & 2166.5 & 1737.8 & 2501.3 & 7809.6 & 6071.8 \\
\hline
\end{tabular}

TOTAL ENERGY CONSUMPTION $\left(10^{12}\right.$ Btu), REGION: 4

Sector

\begin{tabular}{|c|c|c|c|c|c|c|c|}
\hline Fue 1 & Residential & Commercial & Industrial & Transportation & Electric Utility & Tota1 & $\begin{array}{l}\text { Total Less } \\
\text { Transportat }\end{array}$ \\
\hline Coa1 & 15.1 & 8.1 & 446.4 & - & 2607.8 & 3077.4 & 3077.4 \\
\hline 011 & 172.3 & 303.6 & 462.6 & 2990.2 & 590.5 & 4519.2 & 1529.0 \\
\hline NG & 482.0 & 279.9 & 1047.7 & 126.0 & 241.4 & 2177.0 & 2051.0 \\
\hline Nuclear & -- & -- & - & -- & 367.8 & 367.8 & 367.8 \\
\hline Hydro & - & -- & - & -- & 452.6 & 452.6 & $452: 6$ \\
\hline Totals & 669.4 & 591.6 & 1956.7 & 3116.2 & 4260: 1 & 10.594 .0 & $7477 \therefore 8$ \\
\hline
\end{tabular}


Table 3. TOTAL ENERGY CONSLMPTION ( $10^{12}$ Btu), REGION: 5

\begin{tabular}{|c|c|c|c|c|c|c|c|}
\hline \multirow[b]{2}{*}{ Fue 1 } & \multicolumn{7}{|c|}{ Sector } \\
\hline & Res1dent1a1 & Commercial & Industrial & Transportat ion & Electric Ut1lity & Total & $\begin{array}{c}\text { Total Less } \\
\text { Transportation }\end{array}$ \\
\hline Coal & 45.8 & 24.7 & 1605.3 & -- & 3244.0 & 4919.8 & 4919.8 \\
\hline 011 & 515.1 & 626.6 & 889.4 & 3094.3 & 218.5 & 5343.9 & 2249.6 \\
\hline NG & 1849.7 & 837.7 & 1724.8 & 78.0 & 145.7 & 4635.9 & 4557.9 \\
\hline Nuclear & -- & -- & -- & -- & 518.3 & 518.3 & 518.3 \\
\hline Hydro & -- & -- & - & -- & 41.4 & 41.4 & 41.4 \\
\hline Totals & 2410.6 & 1489.0 & 4219.5 & 3172.3 & 4167.9 & 15459.3 & 12287.0 \\
\hline
\end{tabular}

TOTAL ENERGY CONSUMPTION (10 12 Btu), REGION: 6

Sector

\begin{tabular}{ccccc}
\hline Resident1a1 & Commerclal & Industrial & Transportat \\
\cline { 1 - 1 } 0.0 & & 0.0 & 64.8 & -- \\
66.5 & 256.5 & 1481.2 & 2446.5 \\
608.9 & 285.9 & 5103.5 & 280.3 \\
-- & -- & -- & -- \\
-- & -- & -- & -- \\
675.4 & 542.4 & 6649.5 & 2726.8
\end{tabular}

675.4 Transportation

Fue1

$\operatorname{Cos} 1$

011

NG

Nuclear

Hydro

Totals
2726.8
Total Less

Electric Utility

251.0

315.8

315.8

$\begin{array}{lll}111.4 & 4362.1 & 1915.6\end{array}$

$\begin{array}{lll}2173.7 & 8452.3 & 8172.0\end{array}$

51.2

51.2

51.2

86.8

86.8

86.8

$\begin{array}{lll}2674.1 & 13268.2 & 10541.4\end{array}$


Table 4. TOTAL ENERGY CONSIMPPTION ( $10^{12}$ Btu), REGION: 7

\begin{tabular}{|c|c|c|c|c|c|c|c|}
\hline \multirow[b]{2}{*}{ Fue1 } & \multicolumn{7}{|c|}{ Sector } \\
\hline & Res1dent1al & Commerc1al & Industrial & Transportation & E1ectric Utility & Tota1 & $\begin{array}{l}\text { Total Less } \\
\text { Transportation }\end{array}$ \\
\hline Coal & 3.3 & 1.8 & 83.1 & -- & 596.4 & 684.6 & 684.6 \\
\hline 011 & 60.4 & 125.2 & 227.7 & 961.5 & 50.2 & 1425.0 & 463.5 \\
\hline NG & 516.7 & 271.9 & 590.5 & 113.7 & 246.4 & 1739.2 & 1625.5 \\
\hline Nuclear & -- & -- & -- & -- & 79.0 & 79.0 & 79.0 \\
\hline Hydro & -- & -- & -- & -- & 35.1 & 35.1 & 35.1 \\
\hline Totals & 580.4 & 398.9 & 901.3 & 1075.2 & 1007.1 & 3962.9 & 2887.7 \\
\hline
\end{tabular}

TOTAL ENERGY CONSUMPTION (10 ${ }^{12}$ Btu), REGION: 8

$\hat{N}$

\section{Sector}

\begin{tabular}{|c|c|c|c|c|c|c|c|}
\hline Fue1 & Resident1a1 & Conmercial & Industrial & Transportation & Electric Utility & Total & $\begin{array}{l}\text { Total Less } \\
\text { Transportation }\end{array}$ \\
\hline Cosl & 3.6 & 1.9 & 136.1 & -- & 407.1 & 548.7 & 548.7 \\
\hline 011 & 34.3 & 107.9 & 209.0 & 597.0 & 12.0 & 960.2 & 363.2 \\
\hline NG & 261.3 & 143.5 & 284.4 & 17.4 & 62.8 & 769.4 & 752.0 \\
\hline Nuclear & -- & - & -- & -- & 0.0 & 0.0 & 0.0 \\
\hline Hydro & -- & -- & -- & -- & 254.5 & 254.5 & 254.5 \\
\hline Totals & 299.2 & 253.3 & 629.5 & 614.4 & 736.4 & 2532.8 & 1918.4 \\
\hline
\end{tabular}


Table 5. TOTAL ENERGY CONSUMPTION $\left(10^{12}\right.$ Btu), REGION: 9

Sector

\begin{tabular}{|c|c|c|c|c|c|c|c|}
\hline Fue 1 & Res1dent1al & Commercla 1 & Industrial & Transportation & Electric Utility & Tota1 & $\begin{array}{l}\text { Total Less } \\
\text { Transportation }\end{array}$ \\
\hline Coal & .1 & .1 & 61.6 & -- & 181.7 & 243.5 & 243.5 \\
\hline 011 & 20.7 & 145.1 & 504.5 & 2180.1 & $5 ? 3.8$ & 3424.2 & 1244.1 \\
\hline NG & 717.3 & 298.7 & 870.4 & 43.1 & 327.6 & 2257.1 & 2214.0 \\
\hline Nuclear & -- & -- & - & - & 63.7 & 63.7 & 63.7 \\
\hline Hydro & - & -- & -- & -- & 509.4 & 509.4 & 509.4 \\
\hline Totals & 738.1 & 443.9 & 1436.5 & 2223.2 & 1656.2 & 6497.9 & 4274.7 \\
\hline
\end{tabular}

TOTAL ENERGY CONSUMPTION (10 ${ }^{12}$ Btu), REGION: 10

\begin{tabular}{|c|c|c|c|c|c|c|c|}
\hline Fuel & Resident1al & Comme rctal & Industrial & Transportation & Electric Ut1lity & Total & $\begin{array}{c}\text { Total Less } \\
\text { Transportation }\end{array}$ \\
\hline Conl & 1.8 & 1.0 & 25.7 & -- & 6.2 .6 & 91.1 & 91.1 \\
\hline 011 & 59.4 & 136.9 & 203.4 & 678.1 & 6.2 & 1084.0 & 405.9 \\
\hline NG & 97.0 & 77.6 & 270.2 & 19.4 & 20.2 & 484.4 & 465.0 \\
\hline Nuclear & -- & - & - & - & 3.4 .7 & 34.7 & 34.7 \\
\hline Hydro & -- & -- & -- & -- & 1343.0 & 1343.0 & 1343.0 \\
\hline Totals & 158.2 & 215.5 & 499.3 & 697.5 & 1466.7 & 3037.2 & 2339.7 \\
\hline
\end{tabular}


Table 6. TOTAL ENERG: CONSUMPTION (10 ${ }^{12}$ Btu), REGION: UNITED STATES Sector

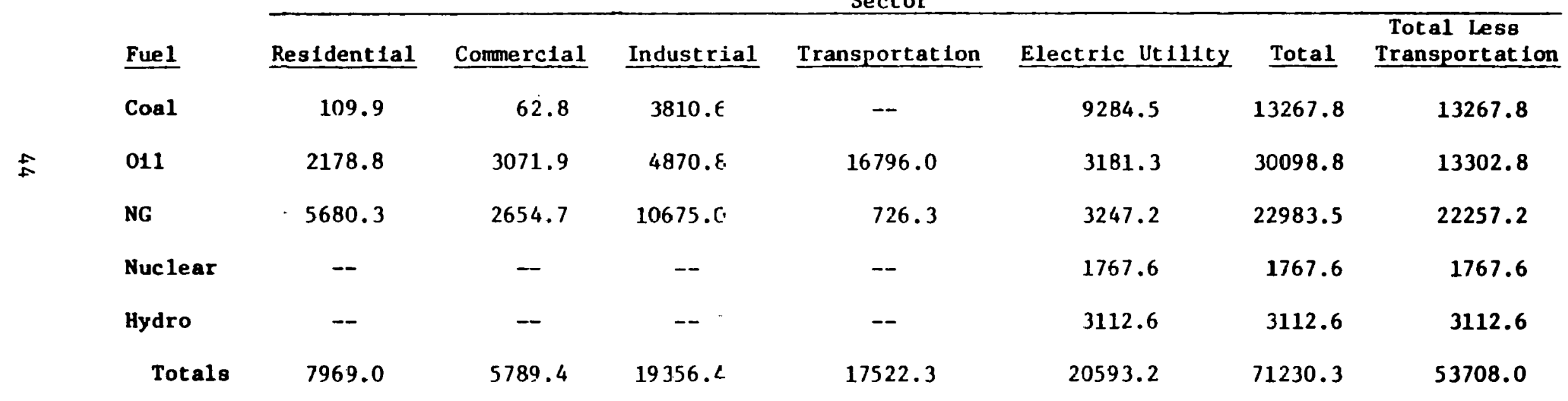


Table 7. REGIONAL ENERGY SIGNIFICANCE

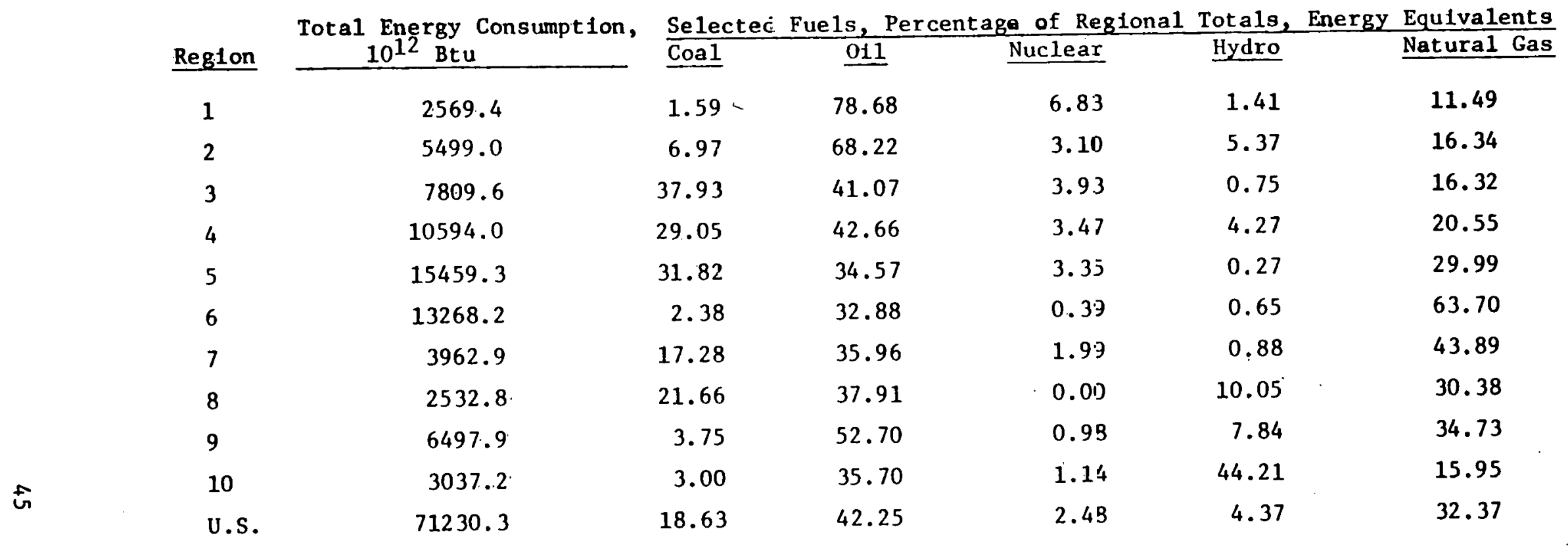


Table 8. REGIONAL ENERGY SIGNIFICANCE, EXCLUDING TRANSPORTATION SECTOR

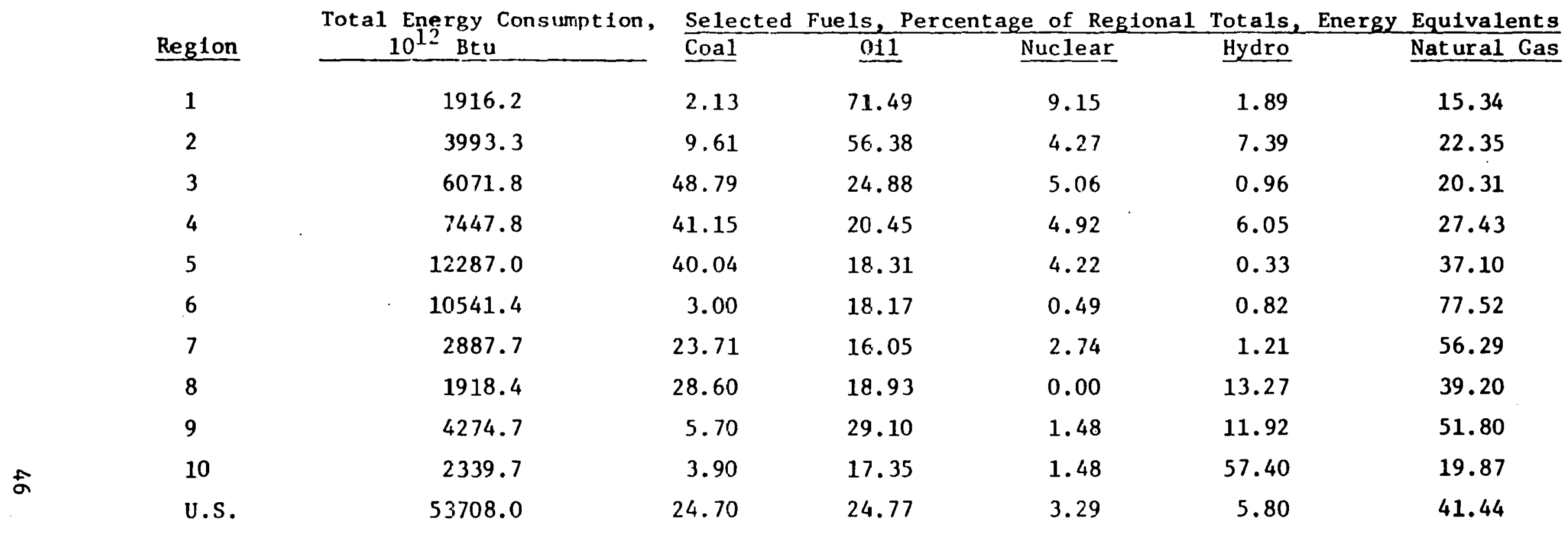


- Transportation Sector. In Region 5, $97.54 \%$ of the energy consumed in the transportation sector 1 derived from o11, compared with $95.85 \%$ nationally, and the remainder (2.46\% regionally, and $4.15 \%$ nationally) is in the form of natural gas.

- Electric Utility. In this sector, coal has a greater regional significance ( $77.83 \%$ of the total energy consumption) than the national average of $45.09 \%$. Oil plays a lesser role ( $5.24 \%$ versus $15.45 \%$ nationally), as does natural gas (3.5\% regionally versus $15.77 \%$ average United States). Nuclear power comprises $12.44 \%$ of the electric utility sector's energy consumption compared with $8.58 \%$ nationally, while hydro electric power generation of less than $1 \%$ regionally is significantly below the U.S. percentage of $15.11 \%$.

Table 7 presents the total energy consumption and a percentage breakdown of energy usage for the ten FEA regions and the United States. As can be seen, Region 5 is more dependent on coal than the national average $(31.82 \%$ versus $18.63 \%$ for the United States), less dependent on oil ( $34.57 \%$ versus $42.45 \%$ ), more dependent on nuclear (3.47\% versus $2.48 \%$ for the United States), and much less dependent on hydro (.27\% versus $4.37 \%)$. The percentage of natural gas in the Region 5 energy mix (29.99\%) compares favorably with the U.S. proportion of $32.37 \%$. Thus, for all the consuming sectors, oil ranks first in Region 5 importance, followed by coal, natural gas, nuclear and hydro. However, if we disaggregate the transportation sector (in which the consumption of ofl is a sine quanon) from the regional percentages, the apparent rankings of importance change significantly. Table 8 displays the adjusted totals and energy source percentages for each region and the United States.

As can be seen, excluding the transportation sector, coal now supplies the largest percentage of Region 5 source energy (40.04\%) followed by natural gas $(37.10 \%)$, oil (18.31\%), nuclear $(4.22 \%)$, and hydro $(.33 \%)$. 
PHYSICAL FLOW OF NATURAL GAS IN REGION 5

Figures 3 through 8 chart the flow of natural gas through the interstate pipeline network which serves the individual states of FEA Region 5. Data necessary for the construction of these charts were extracted from the annual reports which interstate gas pipeline companies are required to file with the Energy Information Administration. (EIA) and from various publications that rely on these reports to present summaries and interpretations of selected information. Classes $A$ and $B$ interstate natural gas pipeline companies (defined as having annual gas operating revenues of $\$ 1$ million or more ${ }^{\star}$ ) file a Federal Power Comission (FPC) Form 2, while Classes C and D pipeline companies (which have gas operating revenues between $\$ 25,000$ and $\$ 1,000,000$ ) file a condensed annual report, the Form 2-A. These latter classes typically account for less then 1\% of all gas sales on file with the Federal Energy Regulatory Commission (FERC).

The National Gas Flow Patterns 1975, published by the Bureau of Natural Gas, was used in the development of the physical flow charts. In that report, data consisting of geographic breakdowns of gas receipts and deliveries, plus Intercompany transactions, were extracted from each interstate pipeline company's annual report. A trlal gas flow pattern was then generated for each company, assuming a proportional gas flow from the point of receipt to the point of delivery. Whenever that assumption proved unrealistic, a single Interstate pipeline company was divided into segments until proportional gas flows were obtained. Intrastate gas volumes were calculated by subtracting the Interstate production and consumption volumes from the total U.S. gas production and consumption volumes. The totals were obtained from sources, such as the U.S. Bureau of Mines, the U.S. Geological Survey, and the American Gas Association. The complexity of the gas flow mechanism from the producing area through the network of interdependent pipeline companies to the ultimate consumers (in this case, the FEA Region 5 marketing areas), an be evidenced

Technically, the interstate pipeline companies are classifed on the basis of annual natural gas operating revenues (GOR's) in the following manner:

- Class A: GOR's in excess of $\$ 2.5$ million

- Class B: $\$ 1$ million to $\$ 2.5$ million

- Class C: $\$ 150,000$ to $\$ 1$ million

- Class D: $\$ 25,000$ to $\$ 150,000$ 


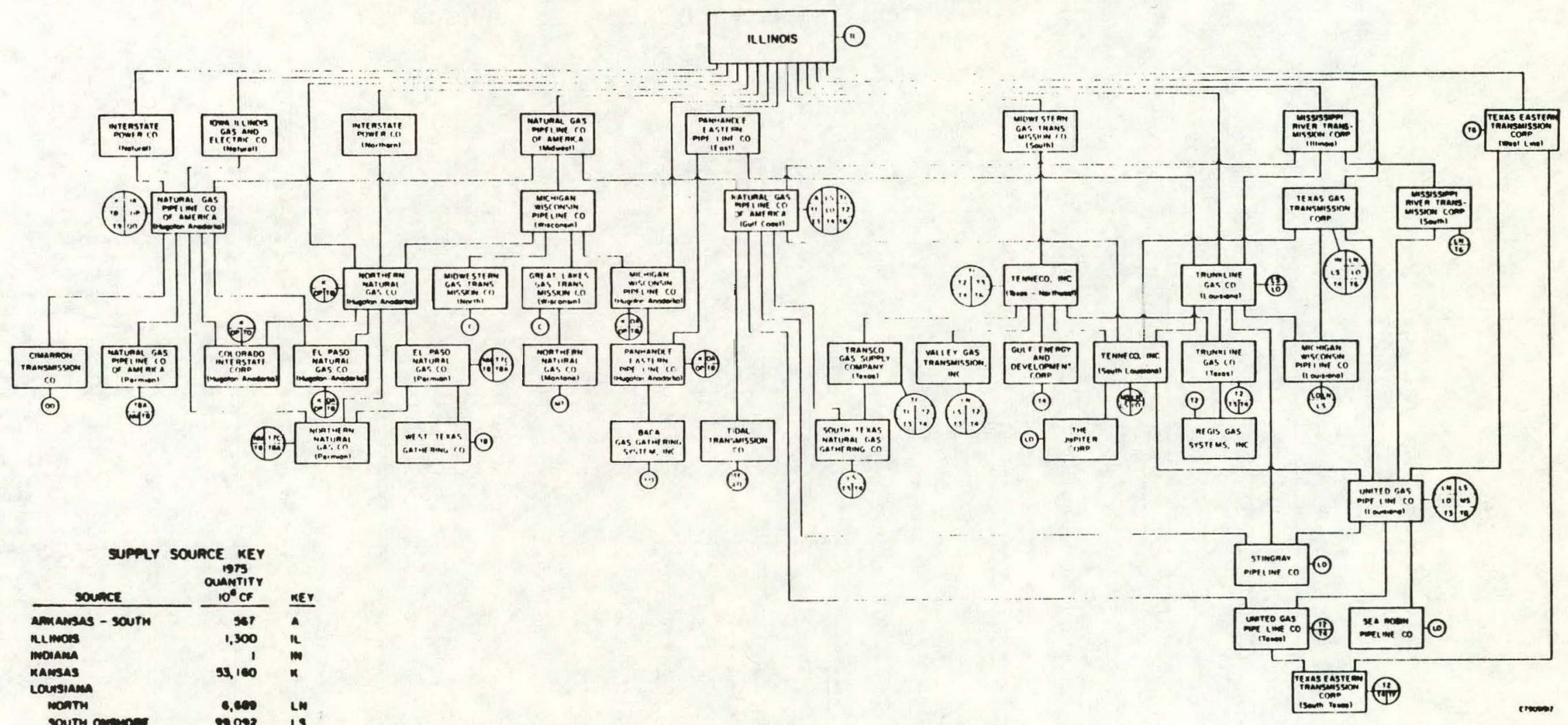

Figure 3. NATURAL GAS FLOW, ILLINOIS

camenos

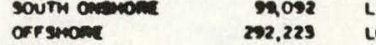

mssissum

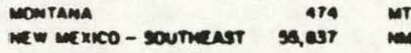

onu anome

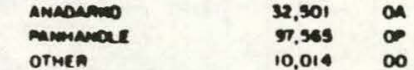

Termen

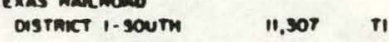

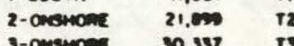

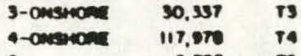

"ive

r-c $\quad 2,000$

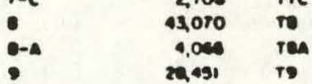

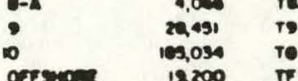

$\quad \frac{2000}{400}$ co 


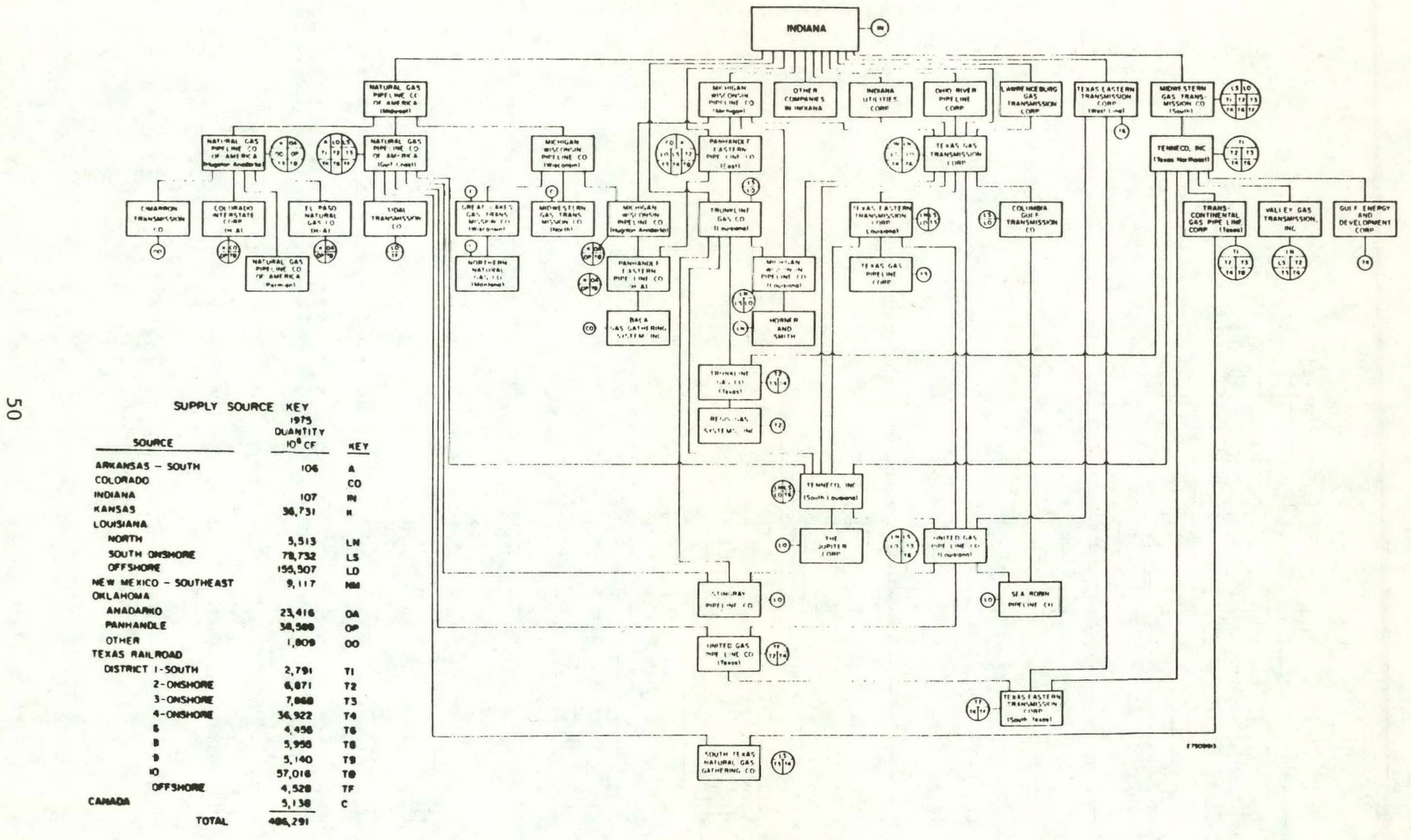

Figure 4. NATURAL GAS FLOW, INDIANA 


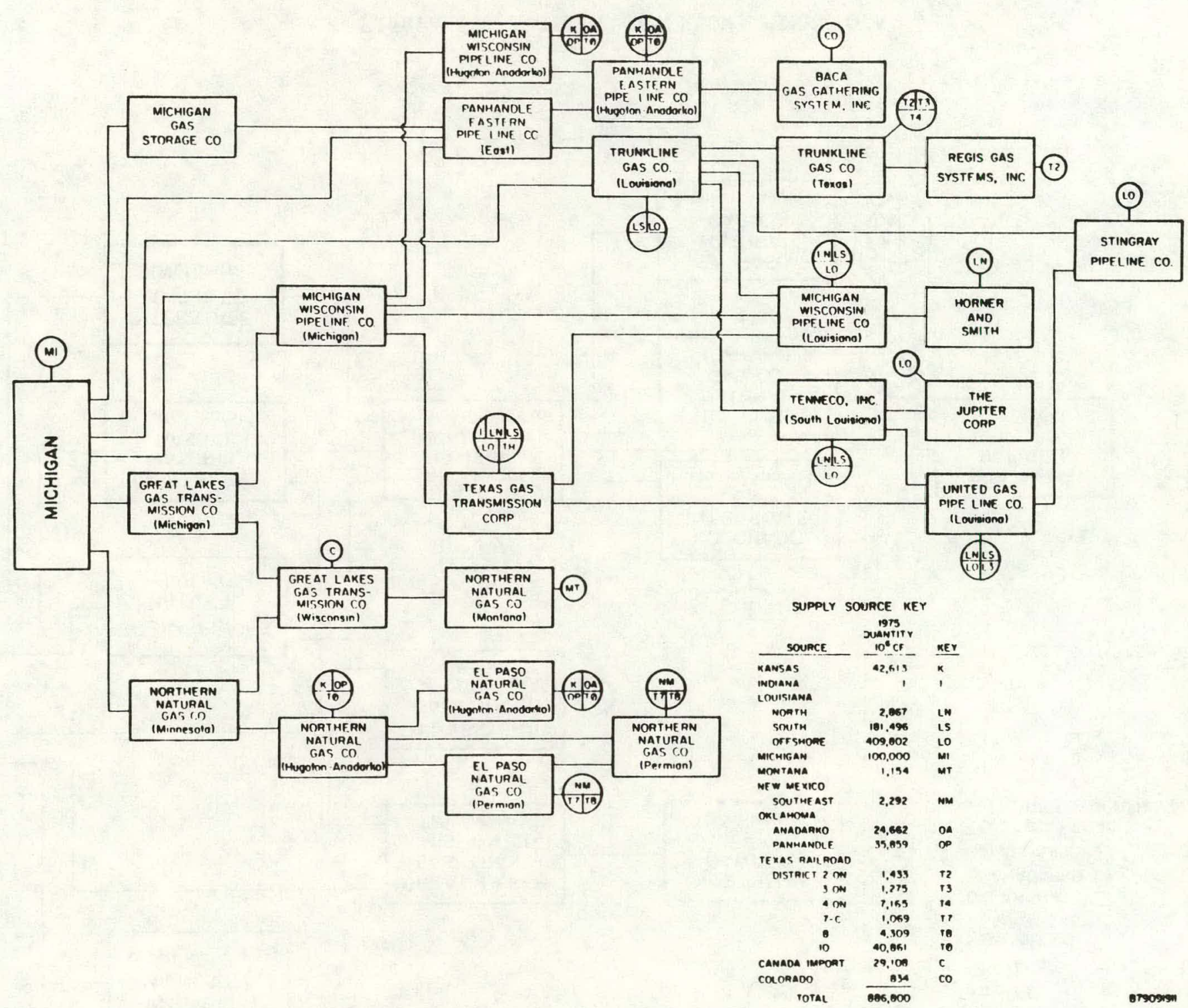

Figure 5. NATUR.AL GAS FLOW, MICHIGAN 
SUPPLY SOURCE KEY

\begin{tabular}{|c|c|}
\hline SOURCE & $\begin{array}{c}1975 \\
\text { QUANTITY, } \\
10^{6} \mathrm{CF} \\
\end{array}$ \\
\hline KANSAS & 70,305 \\
\hline MONTANA & 1,035 \\
\hline $\begin{array}{l}\text { NEW MEXICO } \\
\text { SOUTHEAST }\end{array}$ & 27,227 \\
\hline $\begin{array}{l}\text { OKLAHOMA } \\
\text { ANADARKO }\end{array}$ & 4,765 \\
\hline PANHANDLE & 36,162 \\
\hline $\begin{array}{l}\text { TEXAS RAILROAO } \\
\text { DISTRICT I-NORTH }\end{array}$ & 359 \\
\hline $7-C$ & 17,818 \\
\hline 8 & 51,202 \\
\hline 8-A & 1,948 \\
\hline 10 & 72,322 \\
\hline CANADA & 42,069 \\
\hline
\end{tabular}

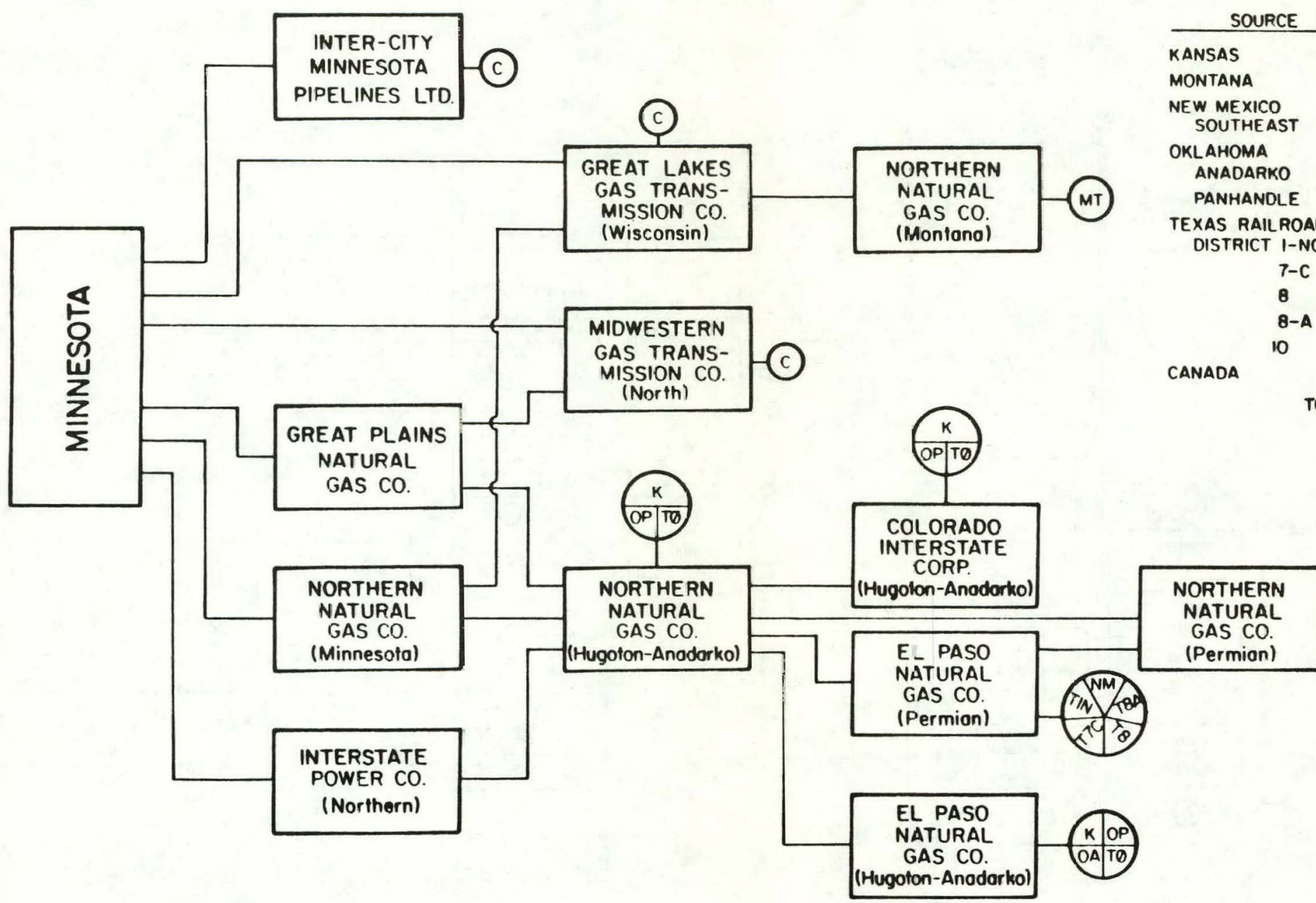

Figure 6. NATURAL GAS FLOW, MINNESOTA 


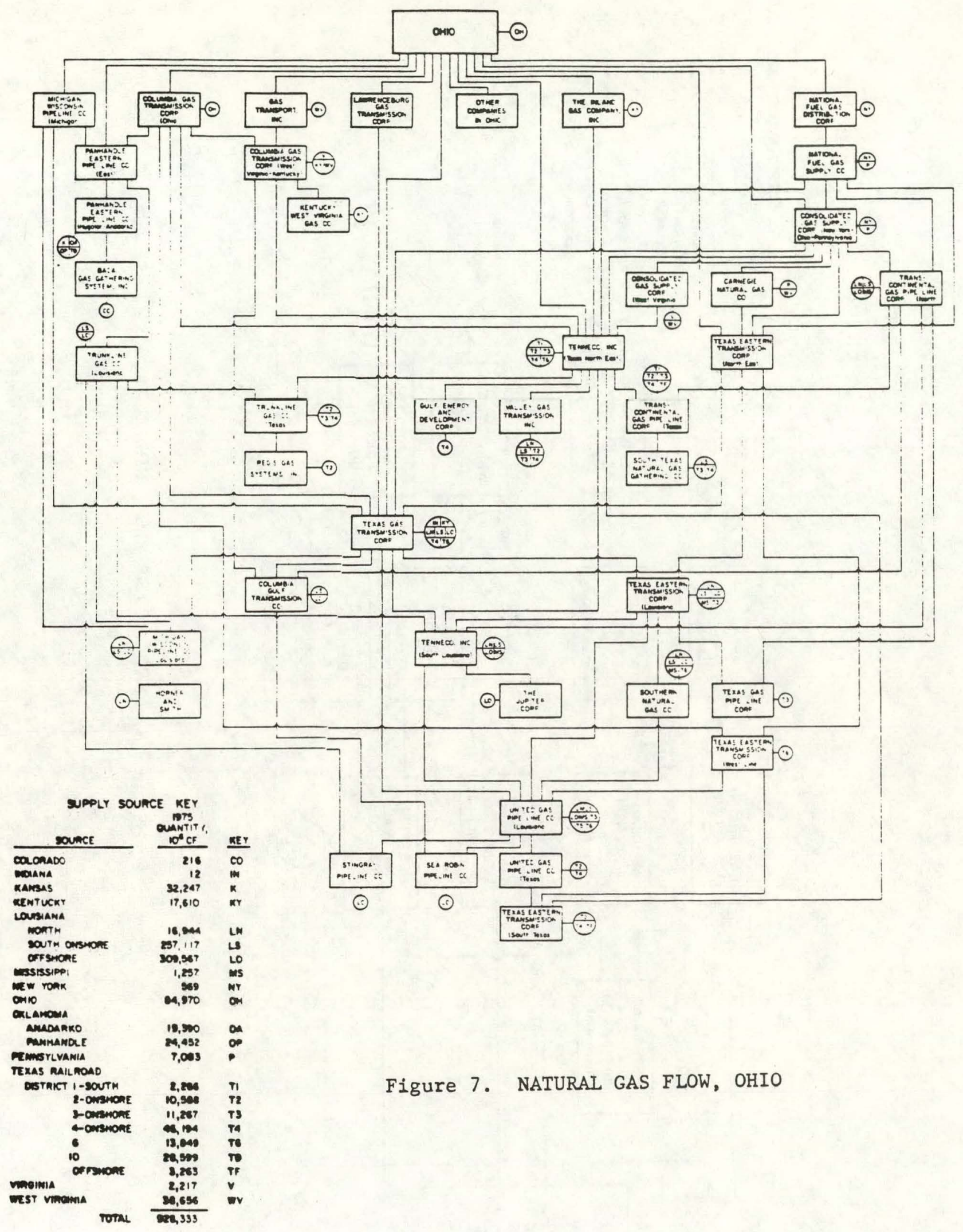




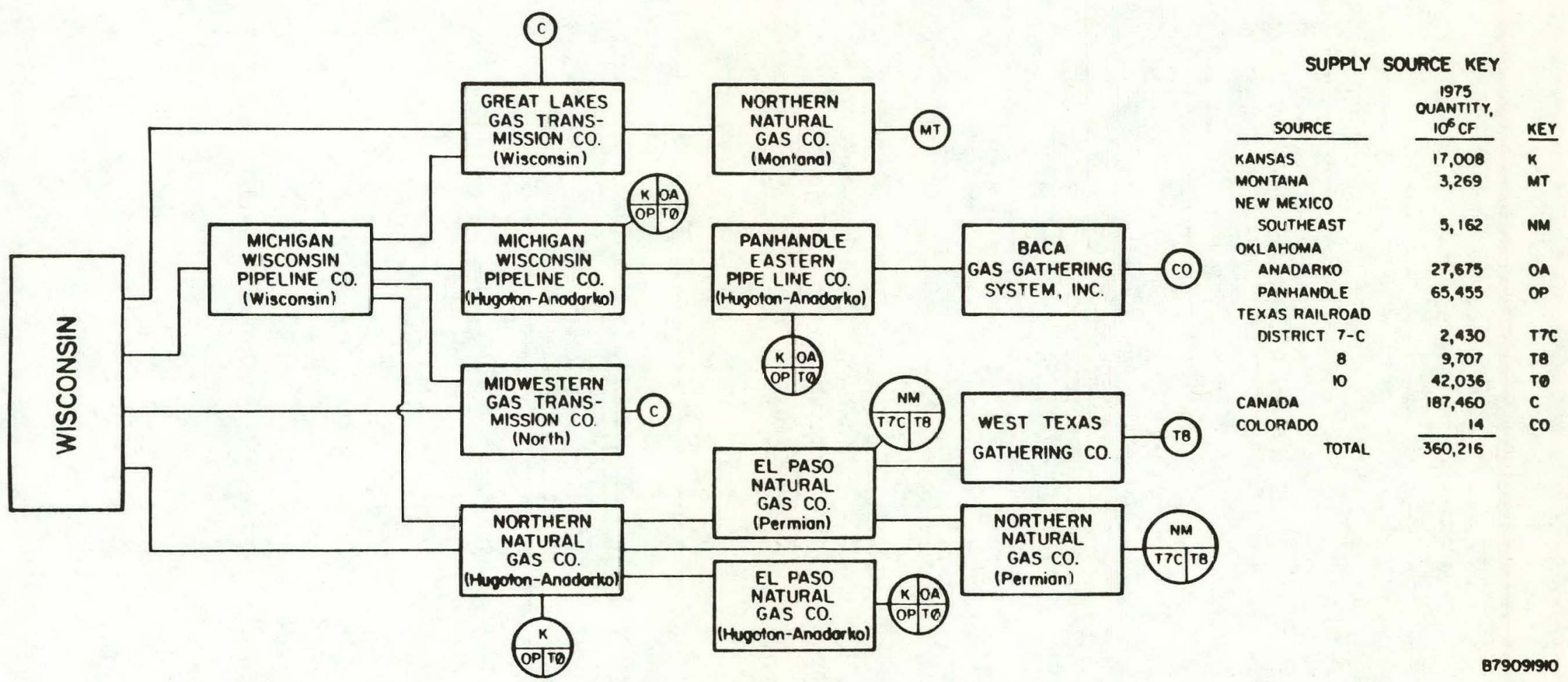

Figure 8. NATURAL GAS FLOW, WISCONSIN 
from these figures. Using Figure 8 for Wisconsin because of its relative simplicity, the method for interpreting all of these figures can be explained.

- Gas flows are assumed to occur in a single direction, 1.e., toward the market area (Wisconsin).

- Certain companies will have an associated segment name which is designated by a set of parentheses. The segment name was arbitrarily chosen, and generally reflects the pipeline origin within a supply area (Texas), or its location relative to another pipeline (north).

- Northern Natural Gas (Permian), West Texas Gathering Co., Baca Gas Gathering System Inc., E1 Paso Natural Gas Co. (Hugaton-Anadarko), and Northern Natural Gas Co. (Montana) represent the interstate pipeline companies serving Wisconsin which receives $100 \%$ of their gas receipts through direct pipeline connection with the supply areas. These supply areas are delineated by a supply source "key" within the connecting circle. The 1975 annual quantity of gas from each of the supply sources to the state within Region 5 is also presented in the "key."

- The flow of gas continues through the network of interstate pipeline companies until it reaches those companies which deliver gas directly into the state marketing area via direct.pipeline connection, e.g., Northern Natural Gas Co. (Hugaton-Anadarko), Midwestern Gas Transmission Co. (north), Michigan Wisconsin Pipeline Co. (Wisconsin), and Great Lakes Gas Transmission Co. (Wisconsin). 


\section{NATURAL GAS FLOWS FROM THE PRODUCING AREAS}

Table 9 displays the 1975 quantities of natural gas from producing areas supplying Region 5. In addition to the total gas volumes from each producing area, the quantities of gas to the Individual states of Region 5, the quantities of natural gas supplied to the interstate market exclusive of Region 5 . and the intrastate market deliveries are shown. Of the $4,132.7 \times 10^{9} \mathrm{SCF}$ of natural gas consumed by the states of Region 5 in the year 1975, about 4.5\%, or $186,423 \times 10^{6} \mathrm{SCF}$, was provided by internal natural gas production. 
Table 9, Part 1. GAS FLOW From THE PRODUCING AREAS

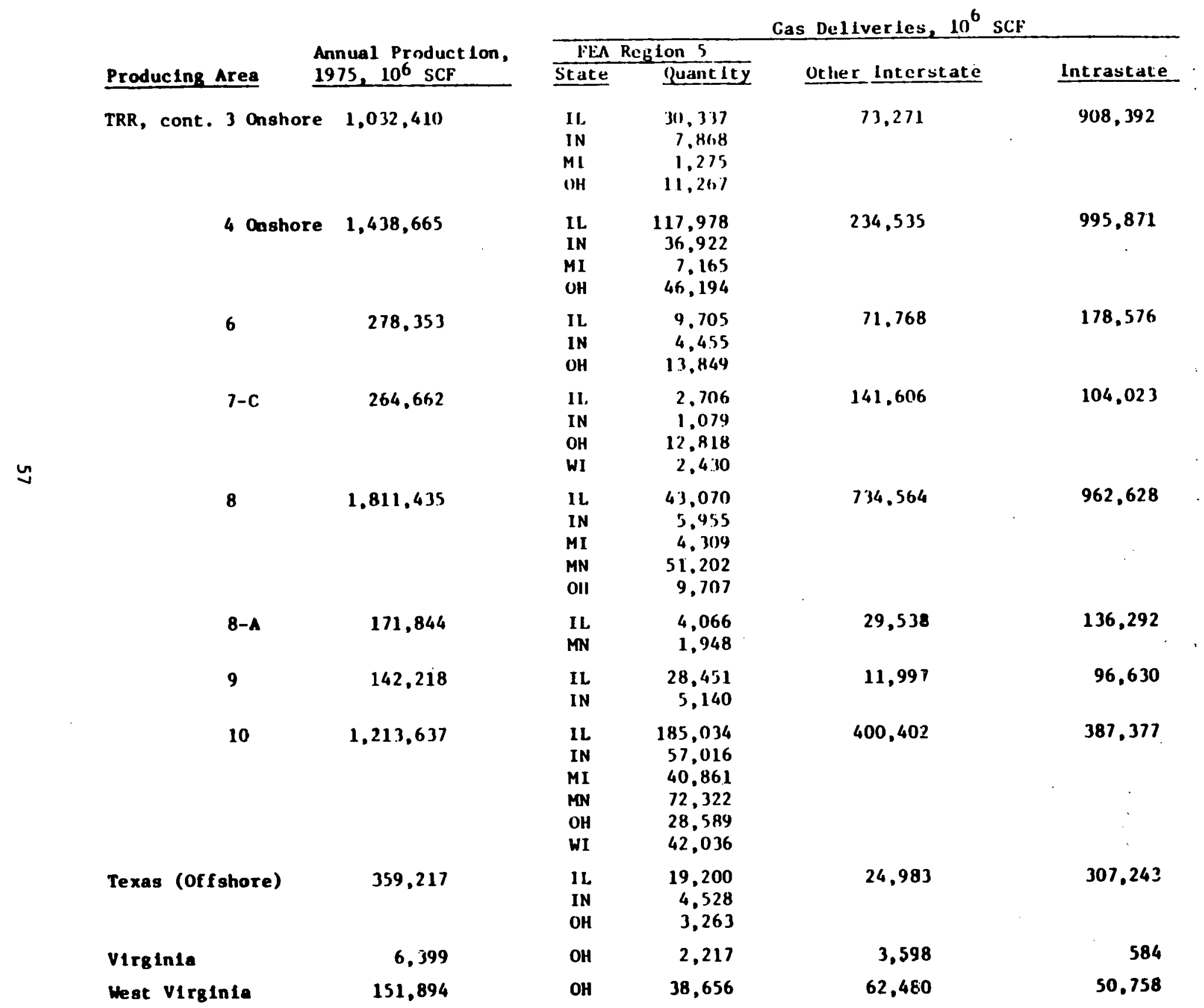


Table 9, Part 2. GAS FLOW FROM THE PRODUCING AREAS

\begin{tabular}{|c|c|c|c|c|c|c|}
\hline \multirow{2}{*}{\multicolumn{2}{|c|}{ Producing Area }} & \multirow[b]{2}{*}{$\begin{array}{l}\text { Annual Product.lon, } \\
1975,10^{6} \text { SCF } \\
\end{array}$} & \multicolumn{4}{|c|}{ Sas Deliveries, $10^{6}$ SCF } \\
\hline & & & $\begin{array}{l}\text { FEA } \\
\text { State }\end{array}$ & $\frac{\text { Reglon } 5}{\text { Quantity }}$ & other Interstate & Intrastate \\
\hline \multicolumn{2}{|l|}{ Michigan } & 100,000 & - & -- & -- & 100,000 \\
\hline \multicolumn{2}{|l|}{ Mississippl } & 71,972 & $\begin{array}{l}\text { IL } \\
\text { OHI }\end{array}$ & $\begin{array}{r}665 \\
1.257\end{array}$ & 37,343 & 32,707 \\
\hline \multicolumn{2}{|l|}{ Montana } & 50,089 & $\begin{array}{l}\text { II } \\
\text { MI } \\
\text { MN } \\
\text { WI }\end{array}$ & $\begin{array}{r}474 \\
1,154 \\
1,053 \\
3,269\end{array}$ & 15,262 & 28,877 \\
\hline \multicolumn{2}{|c|}{ New Mexico (S.E.) } & 602,415 & $\begin{array}{l}\text { IL } \\
\text { IN } \\
\text { M I } \\
\text { MN } \\
\text { WI }\end{array}$ & $\begin{array}{r}55,837 \\
9,1.17 \\
2,292 \\
27,227 \\
5,162\end{array}$ & 407,228 & 95,552 \\
\hline \multicolumn{2}{|l|}{ New York } & 8,669 & $\mathrm{OH}$ & 569 & 3,645 & 4,455 \\
\hline \multicolumn{2}{|l|}{ Ohio } & 84,970 & -- & -- & -- & 84,970 \\
\hline \multicolumn{2}{|c|}{ Oklahoma (Anadarko) } & $61,4,204$ & $\begin{array}{l}\text { IL } \\
\text { IN } \\
\text { MI } \\
\text { MN } \\
\text { OH } \\
\text { WI }\end{array}$ & $\begin{array}{r}32,501 \\
23,416 \\
24,662 \\
4,765 \\
19,390 \\
27,675\end{array}$ & 102,652 & 409,143 \\
\hline \multicolumn{2}{|c|}{ Oklahoma (Panhandle) } & 500,865 & $\begin{array}{l}\text { II } \\
\text { IN } \\
\text { MI } \\
\text { MN } \\
\text { OH } \\
\text { WI }\end{array}$ & $\begin{array}{l}97,565 \\
38,569 \\
35,859 \\
36,162 \\
24,452 \\
65,455\end{array}$ & 231,594 & 71,209 \\
\hline \multicolumn{2}{|c|}{ Oklahoma (Other) } & 434,255 & $\begin{array}{l}\text { IL } \\
\text { IN }\end{array}$ & $\begin{array}{r}10,014 \\
1,809\end{array}$ & 156,056 & 266,376 \\
\hline \multicolumn{2}{|c|}{ Pennsyl van $1 a$} & 83,323 & $\mathrm{OH}$ & 7,083 & 23,251 & 52,989 \\
\hline \multicolumn{2}{|c|}{$\begin{array}{l}\text { Texas Ra11road } \\
\text { Distric:s: } 1 \text { North }\end{array}$} & 30,865 & MN & 359 & 3,495 & 27,011 \\
\hline \multicolumn{2}{|r|}{1 South } & 71,255 & $\begin{array}{l}\text { IL } \\
\text { IN } \\
\text { OH }\end{array}$ & $\begin{array}{r}11,307 \\
2,791 \\
2,266\end{array}$ & 19,253 & 35,638 \\
\hline \multicolumn{2}{|r|}{2 Onshore } & 496,066 & $\begin{array}{l}\text { II. } \\
\text { IN } \\
\text { MII } \\
\text { n'I }\end{array}$ & $\begin{array}{r}21,899 \\
6,871 \\
1,433 \\
10<99\end{array}$ & 66,537 & 388,738 \\
\hline
\end{tabular}


Table 9, Part 3. GAS FLOW FROM THE PRODUCING AREAS

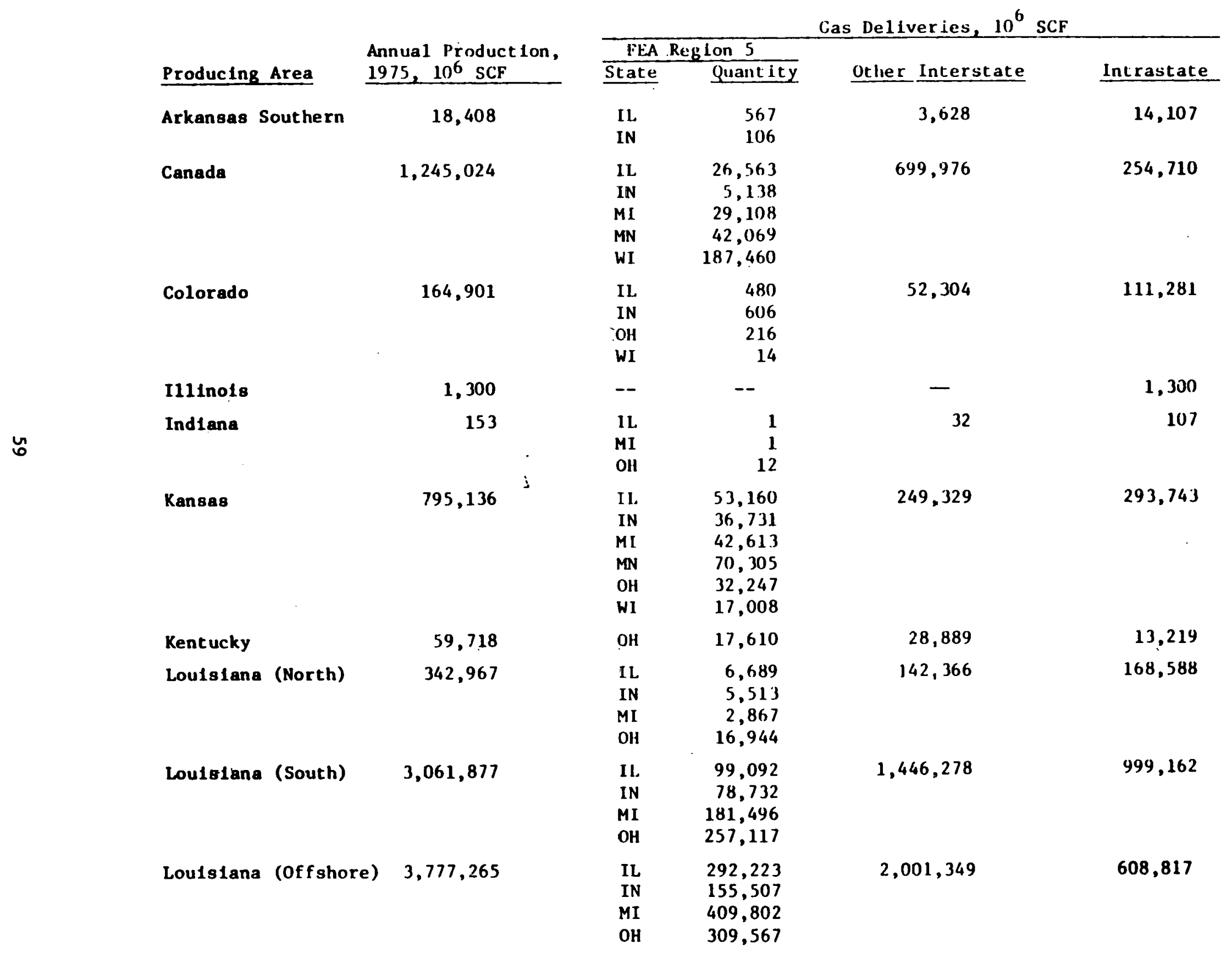


EST DMATED TOTAL PROVED RESERVES IN

PRODUCING AREAS SUPPLYING REGION 5

Table 10 presents the total proved reserves for the producing areas which have been identified as serving Region 5. Proved reserves are defined by the Committee on Natural Gas Reserves of the American Gas Association as being the estimated quantity of natural gas (and natural gas liquids) which, with reasonable certainty, are recoverable from known gas reservoirs under present operating and economic conditions. Known reservoirs are those that have demonstrated the ability to produce, by actual production or conclusive formation testing.

According to the 1975 data presented in this table, the total proved reserves for all the producing areas delivering gas to Region 5 is 174,975,596 $x 10^{6} \mathrm{SCF}$. Of this amount, the proved reserves of Region 5 states comprise only $3,401,402 \times 10^{6} \mathrm{SCF}$, or less than $2 \%$ of the total, and for comparison, only about $82 \%$ (i.e., less than one year of Region 5 consumption) of the 1975 inflows of gas to the region.

Table 11 presents the (1977) total gas reserves of the major FERC Classes $A$ and $B$ interstate natural gas pipeline companies which have been identified as serving Region 5. The quantity of supplemental reserves, the proportion of the individual company's supply to the region, and the individual states served are also displayed.

The total gas reserves are a sumation of reserves available from a number of sources: currently producing and nonproducing gas lands, either owned or leased by the interstate pipeline company; gas supplies available from purchase contracts, including wellhead, field line, gasoline plant outlet, transmission line, and city gate purchases; and reserves available from LNG, SNG, or manufactured gas sources.

Assuming consumption and the proportion of individual company resources supplied to Region 5 remain constant, the 1977 proved resources represent about 11 years of natural gas supply for Region 5 . 
Table 11. TOTAL GAS RESERVES OF CLASSES A AND B SERVING REGION 5

\begin{tabular}{|c|c|c|c|c|}
\hline P1pe11ne Company & $\begin{array}{l}1 \text { Gas Reserves, } \\
10^{6} \mathrm{SCF}\end{array}$ & $\begin{array}{l}\text { Supplemental Supplies } \\
\text { (SNG a LNG), } 10^{6} \text { SCF) } \\
\end{array}$ & $\begin{array}{l}\text { Percent of Compantes } \\
\text { Supply to FEA } \\
\text { Region } 5 \text { (1977) } \\
\end{array}$ & $\begin{array}{c}\begin{array}{r}\text { Region } 5 \\
\text { States Supplied }\end{array} \\
\end{array}$ \\
\hline Columbla Transmission Corp. & $12,098,225$ & 444 & 44 & OH \\
\hline Consolidated Gas Supply Corp. & $7,311,456$ & - & 44 & OH \\
\hline Gas Transport, Inc. & 24,766 & -- & 100 & OH \\
\hline Great Lakes Gas Transmlssion Co. & $1,600,552$ & -- & 37 & $M I, M N, W I$ \\
\hline Great Plains Natural Gas Co. & 34,855 & 34,855 & 94 & MN \\
\hline Inland Gas Co., Inc. & 184,615 & 184,615 & 44 & $\mathrm{OH}$ \\
\hline Inter-City Minnesota Pipelines Ltd. & -- & -- & 43 & MN \\
\hline Interstate Power Co. & 251,409 & 86,782 & 14 & IL, MN \\
\hline Iowa-I1linois Gas and Electric Co. & 682,978 & 682,978 & 27 & IL \\
\hline Lawrenceburg Gas Transmission Corp. & 63,770 & -- & 100 & IN \\
\hline Michigan Gas Storage Co. & 130,686 & -- & 100 & MI \\
\hline Mich1gan Wisconsin P1pe Line Co. & $7,390,099$ & -- & 85 & IL, IN, MI, OH, WI \\
\hline Midwestern Gas Transmission Co. & $3,632,575$ & -- & 95 & IL, IN, MN, WI \\
\hline Mississipp1 River Transmission Corp. & $1,212,533$ & 14,562 & 31 & IL \\
\hline Montana-Dakota Ut111t1es Co. & 630,461 & 4,566 & NA & MN \\
\hline National Fue1 Gas Distribution Corp. & -- & -- & NA & $\mathrm{OH}$ \\
\hline Nattonal Fuel Gas Supply Corp. & $2,021,240$ & -- & 1 & $\mathrm{OH}$ \\
\hline Natural Gas Plpeline Co. of America & $7,941,234$ & -- & 84 & IL \\
\hline Northern Natural Co. & $8,106,248$ & 36,996 & 35 & IL, MI, MN, WI \\
\hline Ohto River Pipeline Corp. & 66,742 & -- & 99 & IN \\
\hline Panhandle Eastern Pipe Line Co. & $6,559,110$. & -- & 62 & IL, IN, MI, OH \\
\hline Tenneco, Inc. & $8,606,228$ & -- & 30 & $\mathbf{O H}$ \\
\hline Texas Eastern Transmission Corp. & $8,745,620$ & -- & 23 & IL, IN, OH \\
\hline Texas Gas Transmission Corp. & $4,959,965$ & -- & 39 & IL, IN, OH \\
\hline Trunk1line Gas Co. & $5,310,665$ & $3,285,498$ & 85 & IL, IN \\
\hline
\end{tabular}


Table 10. ESTIMATED TOTAL PROVED RESERVES OF NATURAL GAS IN PRODUCING AREAS SUPPLYING FEA REGION 5

\section{Producing Area}

Arkansas

Colorado

Illinois

Indiana

Kansas

Kentucky

Louisiana - Total North

South offshore

Michigan

Miss1ssippi

Montana

New Mexico (South)

New York

Oh10

Oklahoma - Total Anadarko Panhandle Other

Pennsylvania

Texas Rallroad Districts: 1

$2 *$

3*

$4 *$

6

7-C

8

8-A

10

Texas offshore

V1rginia

West V1rginia

${ }^{\star}$ Excludes off shore reserves.
Proved Reserves, 1975 $10^{6} \mathrm{CF}$ at $14.73 \mathrm{psia}, 60^{\circ} \mathrm{F}$

$$
\begin{array}{r}
1,993,273 \\
1,893,017 \\
380,804 \\
59,839
\end{array}
$$

$12,661,181$

812,630

$61,309,423$

$2,629,673$

$24,317,646$

$34,362,104$

$1,606,749$

$1,207,627$

929,986

$3,980,840$

215,843

$1,354,010$

$13,083,028$

$5,018,769$

$4,681,130$

$3,383,129$

$1,682,460$

$1,363,529$

$5,690,267$

$15,393,358$

$14,020,855$

4,203,032

$2,086,401$

$12,541,137$

$1,389,787$

$8,490,904$

$2,970,538$

47,465

$2,311,336$ 


\section{EFFECTS OF REGULATED PRICES ON SUPPLIES}

The Natural Gas Act (NGA) of 1938 empowered FERC's predecessor, the Federal Power Commission (FPC), to regulate the interstate sale of natural gas destined for resale. Section $1(b)$ of that act precluded the applicability of the NGA to natural gas production and gathering. Similarly, the mainline direct sales of interstate pipelines to ultimate consumers were exempted, and local natural gas distribution remained under the furisdiction of the individual state utility comissions. Thus, the FPC intially regulated the rates charged by interstate pipelines for transporting natural gas to the distribution companies. Wellheud prices tended to be low because of the prevailing economic conditions (the depression) and the interstate pipeline companies' ab1lity to set field prices. This ability to set prices was, in part, because of the 1solated, monopsonistic markets created by the pipeline system in its early stages, 1.e., an individual pipeline company was often the sole buyer of gas from an individual field operator, who faced the prospect of accepting their terms or discontinuing production.

The FPC continued to divorce themselves from the production and gathering aspects of the natural gas industry, until ordered to do so by the Supreme Court in the year 1954. At that time, the Supreme Court upheld a lower court's decision that a producer was indeed a natural gas company within the intent of the NGA of 1938, and as such, its sales in interstate comerce fell under the jurisdiction of the FPC. Subsequent legislation, initiated to restore the original interpretation of the NGA, failed. President Eisenhower stated that he had vetoed the Harris-Fulbright Act (which was passed by Congress in the year 1956) because of the extensive lobbying by producers prior to its passage and the persistent allegations of legislative improprieties.

Attempts to set wellhead gas rates on a producer by producer, well by well, basis proved futile. The volume of filings between the years 1954 and 1960 (11,000 rate schedules from 3372 producers with an additional 33,000 supplementary filings) led to enormous delays and situations where the FPC determined rates (based on the presented cost and revenue statements) exceeded the existing contractual prices. The FPC decided to abandon this producer and well-specific method in favor of developing rates for geographically homogenous producing areas. Within these areas, a multi-tiered pricing system was established based upon the vintage of individual wells. Subsequent increases were 
granted to encourage new well development during the latter years of 1960 through 1973.

Problems Inherent in the administrative complexity of the area rate and vintage system led to the development of a single national rate for natural gas destined for the interstate market. An initial rate of $42 \mathrm{c} / \mathrm{MCF}$ for gas discovered after January 1, 1973 was established. This ratc was later mudified to 52c/MCF in the year 1975, and an inflation adjustment of $1 \mathrm{c} / \mathrm{MCF} /$ year was allowed. In mid-1976, a fundamentally different policy was undertaken when the national rate for gas developed after January 1, 1975 was established at $\$ 1.42 / \mathrm{MCF}$; the rates for the years of 1973 and 1974 were incremented to 93c/MCF; and gas from existing contracts (developed prior to the year 1973) was set at 52c/MCF. Table 12 illustrates the decline in real gas prices for new interstate contracts during the period of 1953 through 1972 under the various FPC strategies, as rate making was further removed from the cost of service approach.

While the price of gas dedicated to interstate commerce was being regulated by the FPC, intrastate prices were not. Additionally, intrastate demand In the major producing areas had grown from insignificant levels during the monopsonies of the years of the 1930 's to approximately $45 \%$ of the nation's gas volume demand in the year 1978. Table 13 displays the 1975 natural gas production totals for the major producing areas and the proportion of the total marketed in intrastate and interstate commerce. The market price discrepancies led producers to dedicate new production solely to intrastate comerce which, in turn, paved the way for supply/demand disequilibrium in the interstate market. Intrastate wellhead gas prices for the years 1975 and 1976 are presented in Table 14. The reader should compare these prices with the prevailing interstate rates for the respective years which were discussed in the text. 
Table 12. NEW INTERSTATE WELLHEAD GAS PRICES, 1953-1972

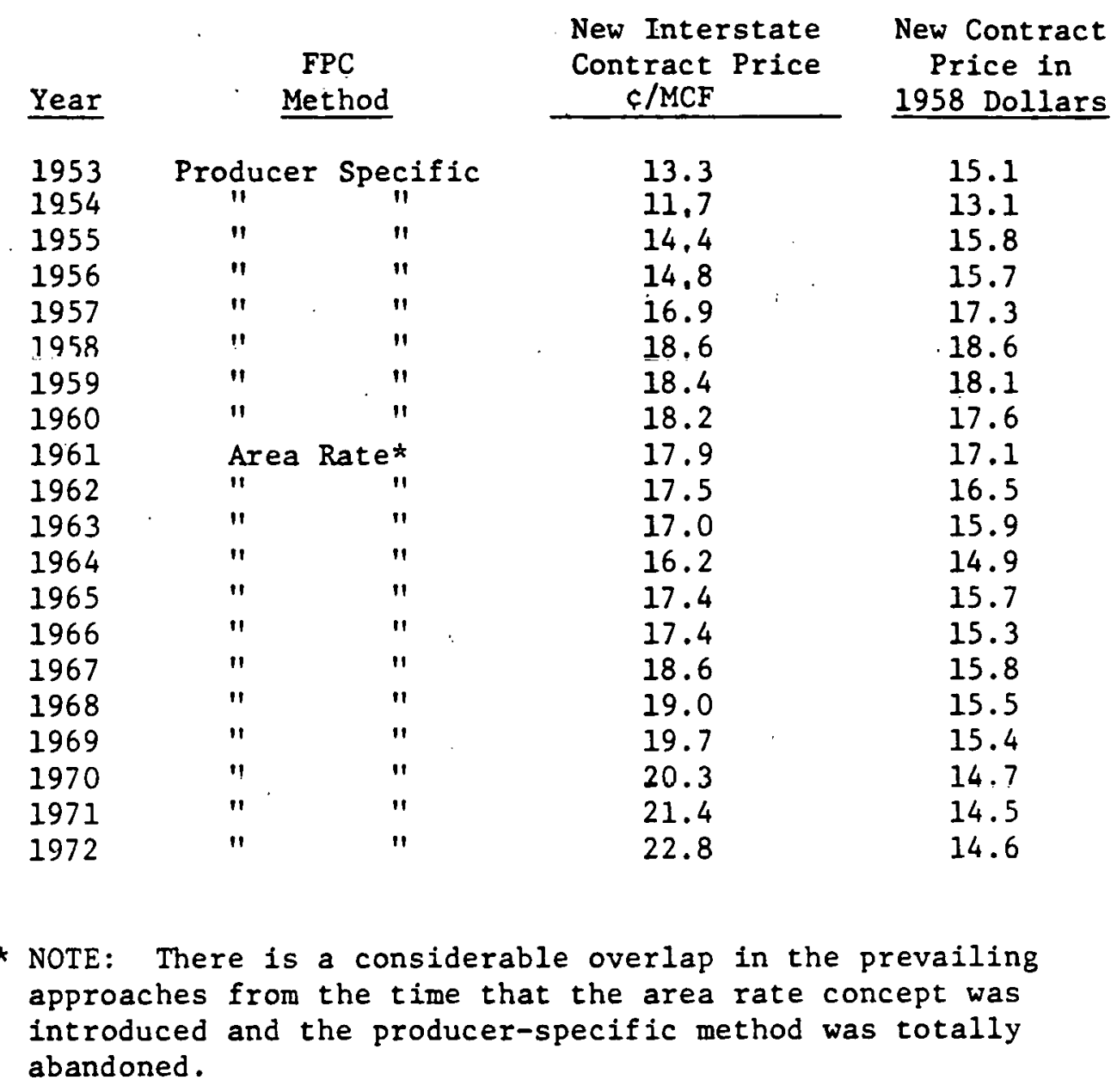


Table 13, Part 1. PROPORTION OF GAS AVAILABlE to INTRASTATE AND. INTERSTATE MARKETS

\section{Producing Area}

Arkansas Southern

\section{Canada}

Colorado

Illinots

Ind I ana

๙

\section{Kansas}

Kentucky

Loulsiana: North

South

of fshore

Michigan

Mississippi

Montana

New Mexico (Southeast)

New York
Annual Production $10^{\text {h }}$ SCF

$$
18,408
$$

$1,245,024$

164,901

1,300

153

795,136

59,718

342,967

$3,061,877$

$3,777,274$

100,000

71,972

50,089

602,415

8,669
Annual Product ion, \%

\begin{tabular}{cr}
\hline Interstate Market & 77 \\
\hline 23 & 22 \\
78 & 67 \\
33 & 100 \\
0 & 68 \\
32 & 36 \\
64 & 23 \\
77 & 49 \\
51 & 34 \\
66 & 18 \\
82 & 100 \\
0 & 46 \\
54 & 58 \\
42 & 16 \\
84 & 51 \\
49 &
\end{tabular}


Table 13, Part 2. PROPORTION OF GAS AVAILABLE TO INTRASTATE AND INTERSTATE MARKETS

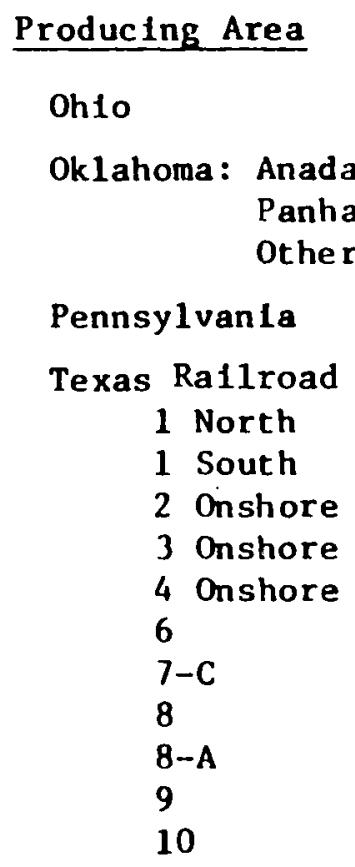

Texas of fhore

Virginia

West Virginia
Annual Production

\begin{tabular}{r}
$10^{6} \mathrm{SCF}$ \\
\hline 84,970 \\
644,204 \\
600,865 \\
434,255 \\
83,323 \\
30,865 \\
71,255 \\
496,066 \\
$1,032,410$ \\
$1,438,665$ \\
278,353 \\
264,662 \\
$1,811,435$ \\
171,844 \\
142,218 \\
$1,213,637$ \\
359,217 \\
6,399 \\
151,894
\end{tabular}

Annual Production, $\%$

\begin{tabular}{cc}
\hline Interstate Market & Intrastate Market \\
\cline { 2 - 2 } 0 & 100 \\
37 & 63 \\
87 & 13 \\
39 & 61 \\
37 & 63
\end{tabular}

86

49

80

90

68

65

39

54

80

68

32

87

13

9

34 
Table 14. INTRASTATE WELLHEAD GAS PRICES

\begin{tabular}{|c|c|c|c|c|c|c|}
\hline & \multicolumn{3}{|c|}{$\$ / M C F$} & \multirow{2}{*}{\multicolumn{3}{|c|}{$\begin{array}{l}\text { Renegotiated or } \\
\text { Arended Contracts }\end{array}$}} \\
\hline & \multirow{2}{*}{\multicolumn{3}{|c|}{$\frac{\text { New Contracts }}{\text { Weighted }}$}} & & & \\
\hline & & & & \multicolumn{3}{|c|}{ Weighted } \\
\hline & High & Average & Low & High & Average & Low \\
\hline 1975 Average & 2.07 & 1.29 & .43 & 2.13 & 1.42 & .26 \\
\hline January & 2.00 & 1.12 & .49 & 2.17 & 1.44 & .21 \\
\hline February & 1.95 & 1.20 & .43 & 2.07 & 1.49 & .76 \\
\hline March & 2.07 & 1.04 & .56 & 2.08 & .76 & .25 \\
\hline April & 2.04 & 1.54 & .20 & 1.91 & 1.67 & .25 \\
\hline May & 2.04 & 1.42 & .44 & 2.08 & 1.46 & .19 \\
\hline June & 2.12 & 1.20 & .47 & 2.32 & 1.58 & .20 \\
\hline July & 2.08 & 1.48 & .31 & 2.35 & 1.52 & .26 \\
\hline August & 2.20 & 1.36 & .30 & 2.17 & 1.06 & .44 \\
\hline Sept ember & 2.14 & 1.42 & .40 & 2.12 & 1.53 & .25 \\
\hline October & 2.03 & 1.05 & .38 & 2.11 & 1.51 & .13 \\
\hline November & 1.94 & 1.36 & .46 & 2.04 & 1.74 & .37 \\
\hline December & 2.16 & 1.34 & .75 & 2.09 & 1.32 & .38 \\
\hline 1976 Average & 2.08 & 1.61 & .49 & 2.19 & 1.64 & .49 \\
\hline January & 2.00 & 1.55 & .14 & 2.21 & 1.84 & .25 \\
\hline February & 2.13 & 1.62 & .15 & 2.21 & 1.70 & .26 \\
\hline March & 1.90 & 3. .52 & .71 & 2.21 & 1.62 & .45 \\
\hline Apr11 & 2.16 & 1.73 & .51 & 2.09 & 1.22 & .18 \\
\hline May & 2.01 & 1.39 & .15 & 2.34 & 1.83 & .16 \\
\hline June & 2.04 & 1.67 & .29 & 2.18 & 1.71 & .49 \\
\hline July & 2.17 & 1.27 & .49 & 2.21 & 1.15 & .20 \\
\hline August & 2.03 & 1.55 & .40 & 2.29 & 1.69 & .80 \\
\hline September & 1.97 & 1.72 & .93 & 2.28 & 1.95 & .97 \\
\hline October & 2.12 & 1.79 & .47 & 2.16 & 1.58 & .48 \\
\hline November & 2.09 & 1.65 & 1.16 & 1.99 & 1.63 & .50 \\
\hline December & 2.33 & 1.85 & .46 & 2.17 & 1.76 & 1.14 \\
\hline 1977 Ave & & & & & & \\
\hline January & 2.35 & 1.81 & .19 & 2.31 & 1.85 & .82 \\
\hline February & 1.98 & 1.66 & .42 & 2.31 & 1.76 & .45 \\
\hline March & 2.39 & 1.91 & .44 & 2.35 & 1.71 & .34 \\
\hline
\end{tabular}

Source: FPC, Bureau of Natural Gas, "Intrastate Gas Prices of FPC Jurisdictional Natural Gas Companies Selling More than One Million Mcf. Per Year in Interstate Commerce," FPC Form 45, 1975-1976. 
The Natural Gas Pollcy Act (NGPA) of 1978 (H.R. 5289, P.L. 95-621) is one of five bills which comprise the National Energy Plan, signed into law on November 9, 1978. A sectional outline of the NGPA is presented in Table 15. The significant general features of the NGPA as it relates to FEA Region 5 follows :

- Dissolution of the "DUAL" Market Structure. Federal price controls now apply to the intrastate, as well as interstate, natural gas market. This effectively reduces the price incentives present in the intrastate markets, thereby enabling the interstate pipelines to compete for the intrastate surplus of natural gas. Gas from "new" production wells and certain other categories can be competed for on an equal basis, because of uniform pricc ceilings.

- Wellhead pricing. Certain categories of natural gas (primarily new natural gas wells) will be deregulated through a gradual program of monthly price escalations. A complete listing of significant categories of natural gas, legislated prices, and date of deregulation (if any) appears in Table 16. State severance taxes may be added to the maximum lawful prices of natural gas with the exception of any severance tax increases subsequent to December 1, 1977 which does not apply on an equal basis to intrastate and interstate gas. This required uniformity prevents the individual states from circumventing the intent of the NGPA with respect to the elimination of artificial market pricing distinctions. Besides these bruad features of the NCPA, several specific sections of the Act (and their subsequent interpretation and implementation) will directly affect the supply of natural gas available to Region 5. Three major regulatory and statutory provisions which can incrase gas flows from the intrastate to the Region 5 market are currently in place. They are Sections $311(\mathrm{~b})$ and 312 of the NGPA, and Emergency Sales.

Section 311(b). This section empowers the Federal Energy Regulatory Commission (FERC) to authorize (by rule or order) any intrastate pipeline to sell natural gas to any interstate pipeline or local distribution company served by an interstate pipeline company at a "fair and equitable" price. This price is a composite of the intrastate pipeline's weighted average gas acquisition cost and a reasonable fee for transportation as specified in Section $311(a)$, which allows interstate and intrastate pipelines to transport gas on behalf of each other, or an associated local distribution company. Section $311(\mathrm{~b})$, implemented by the FERC in March of 1979, provides for a two-year contract duration for these gas sales to the interstate market and contains provisions for renewal. Sales can be terminated if the intrastate pipeline cannot meet its own service requirements or violates any provisions of the NGPA itself. This section of the NGPA should be beneficial to both intrastate pipelines with a large deliverability surplus and interstate pipelines and their associated local distribution companies with excess demand. In a sample two-week period (May 13-26, 1979), FERC reported Section 311 (b) purchases by interstate 
pipelines of roughly $2.618 \times 10^{9} \mathrm{SCF}$ ( $187 \times 10^{6}$ CFD average). Section 311 (b) purchases by distribution companies for this same period totaled $1.400 \times 10^{9} \mathrm{SCF}$ (a $100 \times 10^{6}$ CFD average). Of the total amount, it is impossible to disaggregate the volume of gas destined for Region 5 . One posstble problem which arises when estimating the potential effectiveness of Section $311(b)$ at moving gas to the interstate market concerns intrastate pipelines that have operated under provisions set forth in the Hindshaw amendment to the NGA of 1938. That amendment permitted certifled intrastate pipelines to purchase and sell interstate gas (on a limited basis) in its local market area without being subjected to FPC controls. Such pipelines do not meet the strict NGPA definition for "intrastate pipelines." The extent of the obstruction of intrastate gas flows to the interstate market is again difficult to quantify, especially since several intrastate lines have transferred their $311(b)$ sales to subsidiaries which were not covered by the Hindshaw amendment; or conveyed systems that were covered to their subsidiaries in order to meet NGPA eligibility requirements.

Section 312. This section of the NGPA allows the FERC, by rule or order, to authorlze an intrastate pipeline to assign its right to receive surplus gas at any first sale to an interstate pipeline or local distribution company. This assignment must occur without compensation; can be on a partial basis; and is subject to FERC terms, including possible interruption when that gas is needed to satisfy intrastate customers. It is designed to alleviate the dillemmas of "take-or-pay" arrangements whereby an intrastate line is contractually obligated to take delivery of new gas from a producer on a certain date, or pay the price (its equivalent in penalties) anyway. The FERC reported Section 312 assignments (for the 14-day period of May 13-26, 1979) of $3.459 \times 10^{9}$ SCF (a $247 \times 10^{6}$ CFD average).

- Emergency Sales. The 60-day emergency sales provision, which permits interstate pipelines to purchase intrastate gas is the third major nonprice method for the allocation of gas to interstate commerce. The * authority was granted the FERC (as successor to the FPC) under the NGA* of 1938, later reinforced by the NGPA**, to meet extraordinary winter demands faced by interstate pipelines or local distribution companies. The FERC used their emergency sales authority for making gas available. to the interstate market prior to the implementation of Section $311(\mathrm{~b})$ in March of 1979, and has subsequently allowed this provision to remain in effect. - Only interstate pipelines and distribution companies in curtailment have access to intrastate gas under this program. The cost of gas purchased under this provision is recoverable by the pipelines as long as it does not exceed the ceiling price of new natural gas as defined

ॠ

NGA - Section 2.68 (Policy with Respect to Temporary Emergency Sales and Deliveries of Natural Gas for Resale in Interstate Comerce by Persons with Exemptions Under the Natural Gas Act).

Section 157.22 (Exemption of Temporary Acts and Operation).

Section 157.45 through 157.52 (Exemption of Emergency Sale Arrangements for Natural Gas from Certificate Requirements).

NGPA - Section 284.101 through 284.127 (Certain Transportation of Natural Gas). 
by the NGPA. Although the terms of the emergency sales provision ( 60 days) are insufficient to ensure dependable quantities of natural gas for the interstate pipelines, distribution companies, and the large industrial customer served by them [compared with the maximum two-year duration of Section $311(\mathrm{~b})$ ], there is evidence that this method is used extensively. During the 14-day period of May 19-26, 1979, the FERC reported emergency purcheses of $7.179 \times 10^{9}$ SCF (a $512.79 \times 10^{6}$ CFD average). A FERC estimate of total emergency purchases for the period of November 1, 1978 to March 31, 1979 yielded a quantity of 112.4 trillion $\mathrm{ft}^{3}$, of which 81,5 trilition was purchased by interstate pipelines and 30.9 trillion $\mathrm{ft}^{3}$ by distribution companies. The price range for such purchases was $\$ 1.09$ to $\$ 4.10 / \mathrm{MCF}$. 
Table 15, Part 1. SECTIONAL OUTLINE OF THE NATURAL GAS POLICY ACT OF $1978^{\star}$

BECTION 1. SHORT TIRE; TABLE OF CONTENTS

(a) SHORT TITLE. - This ACt may be cited as the "Natural Gas Policy Act of 1978".

(b) TABLE OF CONTENTS.-

Table of Contents

Sec. 1. Short title; table of contents.

Sec. 2. Definitions.

\section{Title 1-Wellhead Pricing}

Subtitle A-Wellhead Price Controls

Sec. 101. Inflation adjustment; other general price ceiling rules.

Sec. 102. Ceiling price for new natural gas and certain natural gas produced from the Outer Continental Shelf.

Sec. 103. Ceiling price for new, onshore production wells.

Sec. 104. Ceiling price for sales of natural gas dedicated to interstate commerce.

Sec. 105. Ceiling price for sales under existing intrastate contracts.

Sec. 106. Ceiling price for sales under rollover contracts.

Sec. 107. Ceiling price for high-cost natural gas.

Sec. 108. Ceiling price for stripper well natural gas.

Sec. 109. Ceiling price for other categories of natura/ gas.

Sec. 110. Treatment of Stite severance taxes and certain production-related costs.

Subtitle B-Decontrol of Certain Natural Gas Prices

Sec. 121. Elimination of price contro/s for certain natural gas sales.

Sec. 122. Standby price control authority.

Sec. 123. Report to the Congress.

Title II-Incremental Prjeing

Sec. 201. Industrial boiler fuel use.

Sec. 202. Amendment expanding application for other industrial uses.

Sec. 203. Acquisition costs subject to passthrough.

Sec. 204. Method of passthrough.

Sec. 205. Local distribution company passthrough requirements.

Sec. 206. Exemptions.

Sec. 207. Treatment of certain imports.

Sec. 208. Alaska natural gas.

\section{TItle III-Additional Authorities and Requirements}

Subtitle A-Emergency Authorities

Sec. 301

Sec. 302

Sec. 303

Sec. 304.

Declaration of emergency.

Emergency purchase authority.

Emergency allocation authority.

Miscellaneous provisions.

Subtitle B-Othér Authorities and Requirements

Sec. 311. Authorization of certain sales and transportation.

Sec. 312. Assignment of contractual rights to receive surplus natural gas.

Sec. 313. Elfect of certain natural gas prices on indefinite price escalator clauses.

Sec. 314. Clauses prohibiting certain sales, tränsportation, and commingling.

Sec. 315. Contract duration; right of tirst refusal; filing of contracts and agreements. 
Table 15, Part 2. SECTIONAL OUTLINE OF THE

NATURAL GAS POLICY ACT OF 1978

\section{Thte IV-Natural Gas Curtaliment Poliches}

Sec. 401. Natural gas for essential agricullural uses.

Sec. 402. Nalural gas for essential industrial process and feedstock uses.

列

Sec. 403. Establishment and implementation of agricultural and industrial priorities.

Sec. 404. Limitation on revoking or amending certain pre-1969 certificates of public convenience and necessity.

Thtie V_Administration, Enforcement, and Review

Sec. 501. General rulemaking authority.

Sec. 502. Administrative procedure.

Sec. 503. Determinations for qualifying under certain categories of natural gas.

Sec. 504. Entorcement.

Sec. 505. Intervention.

Sec. 506. Judicial review.

Sec. 507. Congressional review.

Sec. 508. Technical amendment.

Title VI-Coordination with the Natural Gas Act; Effect on State Laws

Sec. 601 . Coordination with the Natural Gas Act.

Sec. 602 . Effect on State laws. 
Table 16, Part 1. SUMMARY OF SELECTED GAS PRICES

NGPA CATEGORY OF GAS

NEW NATURAL GAS

- new Outer Continental Shelf (offshore) leases (on or after $4 / 20 / 77$ )

- new onshore wells

1) $2.5 \mathrm{miles}$ from the nearest marker we $11^{5}$

2) If closer than 2.5 miles to a marker we11, 1000 feet deeper than the deepest completion location of each marker well within 2.5 miles

- new onshore reservoirs

Gas from reservolrs discovered after $7 / 27 / 76$ on old (pre-4/20/77) offshore Continental Shelf

NEW ONSHORE PRODUCTION WELLS (we11s, the surface drilling of which began after $2 / 19 / 77$, that are within 2.5 miles of a marker we 11 and not 1000 feet deeper than the deepest completion location in each marker we11 within 2.5 miles)

- gas produced above 5000-foot depth

- gas produced from below 5000-foot depth

GAS DEDICATED TO INTERSTATE COMMERCE BEFORE THE DATE OF ENACTMENT (rates previously set by FPC)

- from wells commenced from $1 / 1 / 75-2 / 18 / 77$

- from we11s commenced from $1 / 1 / 73-12 / 31 / 74$

- from wells commenced prior to $1 / 1 / 73$

- other gas (gas produced by small producers, gas qualifying for special relief rates, etc.) PRICE PER $10^{6} \mathrm{BTU}^{\prime} \mathrm{S}^{1}$

$$
\begin{aligned}
& \$ 1.75+\text { inflation } 2 \\
& \text { and escalation } \\
& (\$ 2.07)^{4}
\end{aligned}
$$

DATE OF

DEREGULATION

$1 / 1 / 85$

APPLICABLE SECTION

OF THE ACT

102
$\$ 1.75+$ inflation

$$
(\$ 1.97)^{4}
$$

$7 / 1 / 87$

$1 / 1 / 85$

Not

Deregulated

$$
\begin{gathered}
\$ 1.45+\text { inflation } \\
(\$ 1.63)^{4} \\
\$ .94+\text { inflation } \\
(\$ 1.06)^{4} \\
\$ .295+\text { inflation } \\
(\$ .33)^{4}
\end{gathered}
$$

App11cable FERC rate

+ Inflation 
DATE OF DEREGULATION

$1 / 1 / 85$ - if contract price exceeds $\$ 1.00$ by $12 / 31 / 84$

- if contract price is less than Section 102 price it may escalate, as called for by contract, up to Section 102 price

- if contract exceeds Section 102 price then contract price plus annual inflation factor or Section 102 price plus escalation applies, whichever is higher

SALES OF GAS MADE UNDER "ROLLOVER" CONTRACTS PRICE PER $10^{6}$ BTU' $^{1}$ Contract price ${ }^{6}$

If lower, not deregulated

\section{- interstate}

- intrastate

HIGH COST NATURAL GAS

- production from below 15,000 feet from wells drilled after $2 / 19 / 77$

- gas produced from geopressurized brine, coal seams, Devontan shale

- gas produced under other conditions the FERC determines to present "extraordinary risks or costs"

\section{$\$ .54$ or other applicable FERC price + inflation$$
(\$ .61)^{4}
$$ \\ The higher of expired contract price or $\$ 1.00+$ inflation

$$
(\$ 1.13)^{4}
$$

$$
\begin{gathered}
\$ 1.75+\text { inflation } \\
+ \text { escalation } \\
(\$ 2.07)^{4}
\end{gathered}
$$

\section{Not}

Deregulated

$1 / 1 / 85$ if more

than $\$ 1.00$

APPLICABLE SECTION OF THE ACT

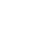


Table 16, Part 3. SUMMARY OF SELECTED GAS PRICES

NGPA CATEGORY OF GAS

STRIPPER WELL NATURAL GAS

(natural gas not produced in association with crude ol1, which is produced at an average rate less than or equal to 60,000 cubic feet per day over a 90-day perlod)

\section{OTHER CATEGORIES OF NATURAL GAS}

- any natural gas not covered under any other section of the bill

- natural gas produced from the Prudhoe Bay area of Alaska
DATE OF

PRICE PER $10^{6}$ BTU $^{\prime} S^{1}$

$\$ 2.09+$ inflation

(after 5/78) +

escalation ${ }^{3}$

$(\$ 2.21)^{4}$

$\$ 1.45$, or other "just and reasonable" rate Deregulated set by FERC, + inflation

$$
(\$ 1.63)^{4}
$$

1. Under the NGPA, If natural gas qualifies under more than one price category the seller may be permitted to collect the higher price. The celling prices set by the NGPA do not include state severance taxes.

2. These prices include an "annual inflation adjustment factor" in order to adjust prices for inflation. The price for a given month is arrived at by multiplying the price for the previous month by the monthly equivalent of the annual inflation factor. Since most of the prices set by the NGPA are as of April 20, 1977, the adjustiment for inflation begins in May 1977.

3. These prices will escalate monthly, in addition to the inflation adjustment factor, by an annual rate of 3.5 percent unt11 April 1981, after which they will escalate by 4 percent.

4. The estimated maximum celling price as of October 1978, due to operation of inflation and escalation adjusters.

5. A marker we11 is any well from which natural gas was produced in commercla1 quantities after January 1 , 1970, and before Apri1 20, 1977, with the exception of wells the surface dr1lling of which began after February 19, 1977.

6. The average price reported to the FERC for intrastate gas sales contracted for during the second quarter of 1978 was approximately $\$ 1.90$.

Source: FERC 
SHORT-TERM EFFECTS OF THE NGPA

The following information was obtained through a series of proprietary interviews with selected interstate pipeline companies. Together these companies account for the majority of the natural gas produced for, transported to, and sold within FEA Region 5.

- Typically, between $80 \%$ and $90 \%$ of the company's current (1978) supply volume is locked into current contract terms through the year 1985 .

- Generally, only a few minor contracts (representing less than $5 \%$ of the 1978 supply volume) are without area rate clauses.

- Because of FERC regulations requiring a hearing on abandonment proceedings (upheld by the U.S. Supreme Court in June of 1979), all expiring contracts are expected to be renewed.

- New contracts are typically providing for payment of the maximum allowable NGPA prices, terms of 15 years (in the past, a 20-year contract was standard), and daily acceptance of between $80 \%$ and $90 \%$ of deliverability.

- All companies surveyed plan to maintain their current sales or reserve life index, and are confident of their ability to do so. This index is a ratio of the total annual sales volume to the total gas supply available from all sources. Two methods of assuring supply decreased in usage during 1978. Gas prepayments by d1stribution companies to interstate pipelines, and advance payments by the interstate pipelines to others for exploration, development, or transporting gas prior to delivery, were declining.

- Gas sales on the wholesale level were expected to remain stable through the year 1985. All expressed some concern that the incremental pricing provistons of the NGPA (which, at the time, had not been implemented by the FERC) would lead to a loss of industrial sales at the retail level because of a lack of sensitivity with alternate fuel pricing.

- The companies surveyed generally report increased short-term supply opportunities as a result of the NGPA. As a result, curtailments have been lessened and more gas made available on a best efforts basis. 